\begin{tabular}{|l|l|l|l|}
\hline $\begin{array}{l}\text { Eiszeitalter und Gegenwart } \\
\text { Quaternary Science Journal }\end{array}$ & $\mathbf{5 7 / 1 - 2}$ & $25-51$ & Hannover 2008 \\
\hline
\end{tabular}

\title{
Magnetic dating of Quaternary sediments, volcanites and archaeological materials: an overview
}

\author{
Ulrich Hambach, Christian Rolf \& Elisabeth Schnepp ${ }^{*}$
}

\begin{abstract}
Magnetic dating includes all approaches dealing with the temporal variation of the Earth's magnetic field (EMF) as well as with the application of climate dependent variations of rock magnetic properties of sedimentary sequences and their correlation to independently dated palaeoclimatic archives. Palaeomagnetism has an outstanding impact on geosciences in general and especially on Quaternary chronology and palaeoclimate research. Palaeomagnetic dating employs the temporal variation of the direction as well as the intensity of the EMF on time scales from $10^{2}$ to $10^{7}$ years. The well-known temporal pattern of reversals of the EMF on time scales from $10^{4}$ to $10^{7}$ years and the shorter secular variation (amplitude 10-30 ${ }^{\circ}$, time scale 1 to $10^{3}$ years) provide an excellent tool for stratigraphic subdivisions. Records of the intensity variations of the EMF as well as the indirect dating by means of correlating rock magnetic property variations from sedimentary archives to dated palaeoclimatic records also serve as dating tools. Field methods as well as laboratory methods and techniques in data analysis will not be discussed in this paper. It is our aim to give a short and subjective overview on palaeomagnetism and magnetic susceptibility stratigraphy as dating tools in Quaternary science.
\end{abstract}

[Magnetische Datierung quartärer Sedimente, Vulkanite und archäologischer Materialien: Ein Überblick]

Kurzfassung: Unter magnetischer Datierung versteht man sowohl die Verfahren, die die zeitlichen Variationen des Erdmagnetfeldes (EMF) zur Altersbestimmung benutzen, als auch die Verwendung der klimaabhängigen Änderungen der gesteinsmagnetischen Parameter und ihre Korrelation mit unabhängig datierten paläoklimatischen Archiven. Die Paläomagnetik hat einen herausragenden Einfluss auf die Geowissenschaften genommen und im Besonderen zur Etablierung der Chronologie des Quartärs und der Paläoklimaforschung beigetragen. Die paläomagnetische Datierung benutzt die zeitlichen Variationen der Richtung wie der Intensität des EMFs auf Zeitskalen von $10^{2}$ bis $10^{7}$ Jahren. Das wohlbekannte zeitliche Muster von Polaritätswechseln des EMFs auf Zeitskalen von $10^{4}$ bis $10^{7}$ Jahren wie auch die Säkularvariation (Amplitude 10-30 Zeitskala 1 bis $10^{3}$ Jahre) stellen ein hervorragendes Werkzeug für die Unterteilung von sedimentären oder vulkanischen Gesteinsabfolgen dar. Aufzeichnungen der Änderungen der Intensität des EMFs sowie die indirekte Datierungen über den Vergleich der Variation gesteinsmagnetischer Parameter in Sedimentarchiven mit anderen datierten Paläoklimaserien können ebenfalls zur Datierung herangezogen werden. Weder die Methoden im Gelände und im Labor, noch die Techniken der Datenanalyse werden in dieser Publikation angesprochen. Unser Ziel ist vielmehr, einen kurzen und subjektiven Überblick über die Paläomagnetik bzw. magnetische Suszeptibilitätsstratigraphie als Datierungswerkzeug in der Quartärforschung zu geben.

Keywords: magnetic dating, Quaternary, palaeomagnetism, secular variation, magnetic susceptibility, stratigraphy

* Addresses of authors: U. Hambach, Chair of Geomorphology, Laboratory for Palaeo- and Enviro-Magnetism (PUM), University of Bayreuth, 94450 Bayreuth, Germany. E-Mail: ulrich.hambach@uni-bayreuth.de; C. Rolf, Leibniz Institute for Applied Geosciences (GGA), Stilleweg 2, 30655 Hannover, Germany. E. Schnepp, Chair of Geophysics, University of Leoben, Gams 45, 8130 Frohnleiten, Austria 


\section{Introduction}

Palaeomagnetism, as a generic term for several sub-disciplines in geomagnetism (e.g., magnetostratigraphy, apparent polar wander, archaeomagnetism), is an essential part of geosciences. Its outstanding impact on geosciences in general and on the development of the model of plate tectonics in particular is widely appreciated. Rock magnetism (environmental magnetism) became famous in Quaternary research after its successful application as magnetic susceptibility stratigraphy for indirect dating of Asian loess deposits and their correlation to the global ice volume record.

The success and achievements of palaeo- and rock magnetism in earth sciences are amongst others, proven by the plenitude of monographs on these topics. For a deeper insight into the methods of palaeomagnetism, we refer to following textbooks without any claim for completeness (in chronological order): ColLINSON et al. (1967), McElhinny (1973), Stacey \& Banerjee (1974), Collinson (1983), Tarling (1983), Thompson \& Oldfield (1986), Soffel (1991), Butler (1992), VAN Der Voo (1993), Opdyke \& Channell (1996), Dunlop \& ÖzDEMIR (1997), TAuXe (1998), Maher \& THOMPSON (1999), McElhinny \& McFadden (2000), Evans \& Heller (2003), Lanza \& Meloni (2006).

Field methods as well as laboratory methods and techniques in data analysis will not be discussed here. For these topics we refer to textbooks (e.g., Collinson 1983; Butler 1992).

This paper does not want to appear as a textbock in miniature. The aim of this paper is to give a short overview on palaeomagnetism and magnetic susceptibility stratigraphy as dating tools in Quaternary science and to draw the reader's attention to the possibilities and problems of the methods.

\section{The Earth's magnetic field}

Our planet is surrounded by a magnetic field. The intensity of the Earth's magnetic field (EMF) on its surface is extremely weak



Fig. 1: Sketch of the Earth magnetic field (EMF) lines displaying its dipole character. Note the deviation of the dipole axis (dashed line) from the Earth's rotation axis. Redrawn from SchNEPP (2007).

Abb. 1: Skizze der Feldlinien des Erdmagnetfeldes (EMF), welche den Dipolcharakter des Feldes anzeigt. Zu beachten ist auch, dass die Dipolachse (gestrichelte Linie) im Vergleich zur Rotationsachse der Erde geneigt ist (nach ScHNEPP 2007).

$\left(30.000-60.000 * 10^{-9}\right.$ (nano) Tesla) compared with technically used magnetic fields. It is, for example, several hundred times weaker than the field between the poles of a toy horseshoe magnet (J ACOBS 1994). Monitoring the EMF in observatories all over the world during the last 400 years demonstrates its dominant dipole character. This dipole is inclined by about $10^{\circ}$ against the rotation axis of the Earth (Fig. 1) today. The main elements (components) of the geomagnetic field vector are declination (D) and inclination (I) measured in degrees, the intensity of the total field (F) described by the horizontal component $(\mathrm{H})$ and the vertical component $(Z)$ pointing downwards into the Earth on the northern hemisphere (Fig. 2a). Declination describes the deviation of a compass needle (magnetic north) from true (geographic) north. Inclination is the angle between the horizontal plane and the total field vector, measured positive into the Earth. At the magnetic poles, the magnetic needle of an inclinometer points vertically; the horizontal intensity is zero, while total intensity reaches the maximum. At the magnetic equator, the 
inclination is zero and the horizontal component is about half of the intensity at the pole. Accordingly, inclination as well as F, $\mathrm{H}$ and $\mathrm{Z}$ depend on the geographic latitude (Fig. 2b).

The elements of the geomagnetic field vary on time scales ranging from days to tens of millions of years owing to complex magneto-hydrodynamic processes that generate the geodynamo in the outer liquid core of the earth. The extent of these temporal changes is dependent upon the location on Earth due to non-dipole sources of the EMF. In terms of directional changes with time, we have to differentiate between three features: the most prominent is called geomagnetic polarity reversal, meaning a $180^{\circ}$ flip of declination and a change of sign of the inclination (Fig. 3), i.e. the dipole would point to the geographic North Pole in Figure 1. The duration of such a transition is in the order of $10^{3}$ to $10^{4}$ years. Superimposed to this relatively abrupt and large change during a reversal, is a background variability of angular variation $\left(10-30^{\circ}\right)$ called secular variation (SV). This movement of the geomagnetic elements occurs on time scales from 1 to $10^{3}$ years. The third feature is called geomagnetic excursion. This describes an incomplete reversal or a short time interval of anomalously high secular variation (more than $30^{\circ}$ ). This phenomenon is not fully understood at present. The strength of the field vector (intensity) varies with time on the same time scales, but the long-term behaviour is not well understood, because the little data that is available is also poor. Secular variation of intensity is in the order of $\pm 50 \%$ of the present field strength, while during excursions and reversals a strong decay in intensity down to about $10 \%$ of the present intensity is observed (MERRILL et al. 1996). Palaeointensity is much more difficult to measure and its palaeomagnetic determination needs more complicated procedures than determination of palaeodirection. While measurements of the palaeofield direction are quick and applicable to most kinds of rocks, special conditions are needed for a successful determination of the absolute palaeointensity.

It is the main task of palaeomagnetism to identify the ancient geomagnetic direction and in-
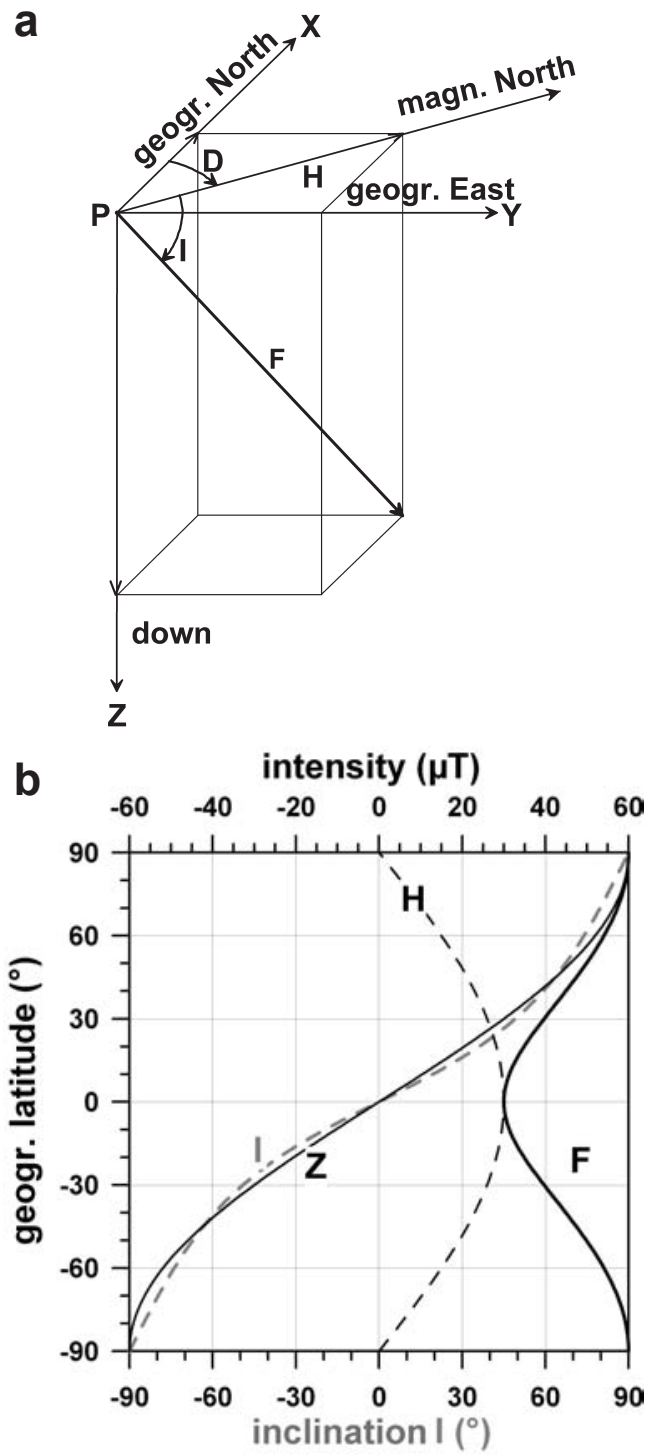

Fig. 2: (a) Earth magnetic elements shown in a Cartesian coordinate system at a point $\mathrm{P}$ of the Earth's surface (redrawn from ScHNEPP, 2007), (b) dependence of inclination (I) as well as total (F), horizontal $(\mathrm{H})$ and vertical $(\mathrm{Z})$ intensity (black) on geographic latitude.

Abb. 2: (a) Die erdmagnetischen Elemente sind in einem kartesischen Koordinatensystem für einen Punkt P auf der Erdoberfläche dargestellt (verändert nach Schnepp 2007); (b) zeigt den Zusammenhang zwischen Inklination (I) bzw. Total- (F), Horizontal$(\mathrm{H})$ und Vertikalintensität ( $\mathrm{Z}$, jeweils schwarz) und der geographischen Breite . 

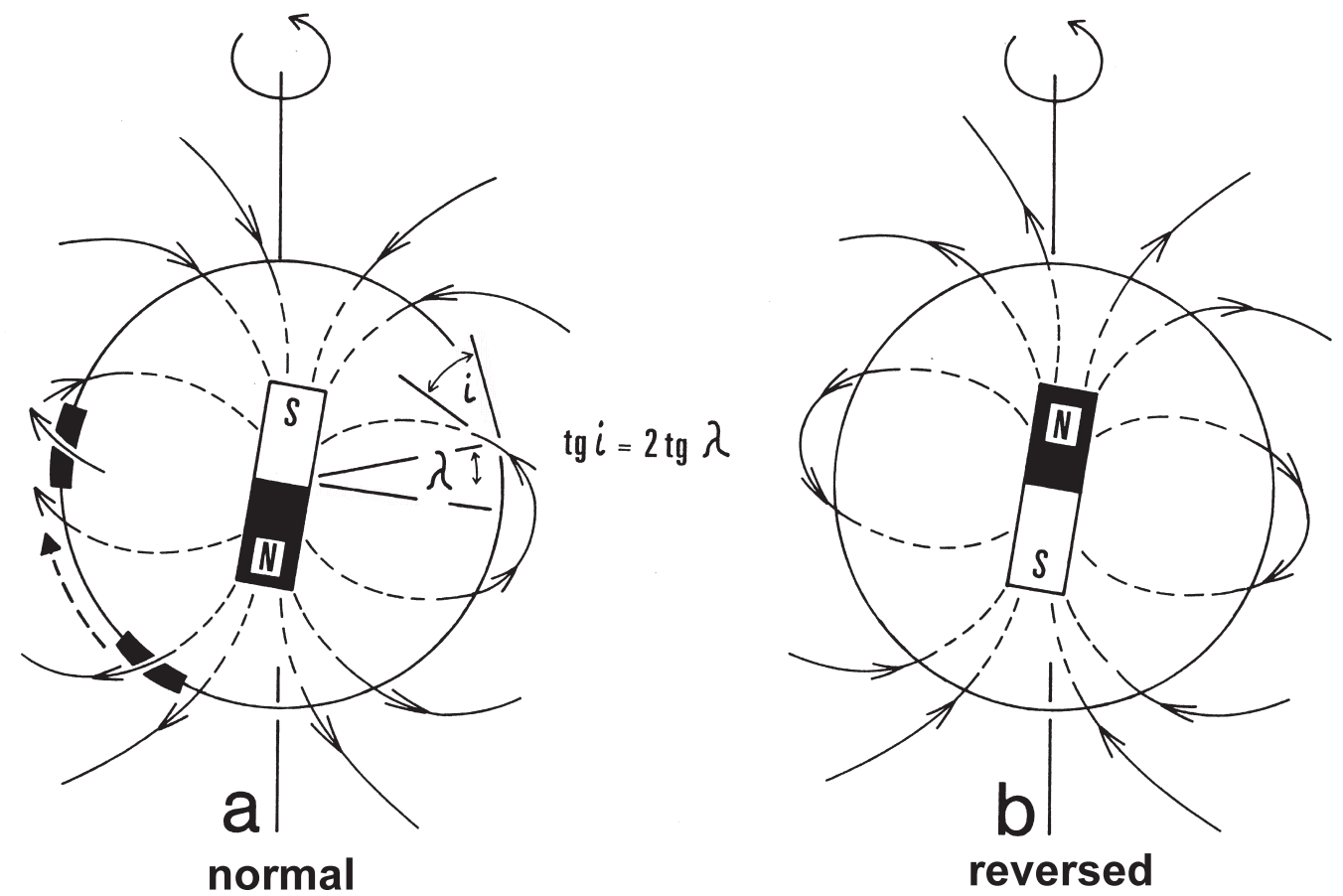

Fig. 3: Sketch of the Earth's magnetic dipole field in normal (a) and reversed (b) state. The bar magnet in the Earth's centre symbolizes the virtual dipole moment which is the main element of the EMF. Note the orientation of magnetic South and North. Also given is the dependence (dipole formula, see Fig. 2 (a)) of inclination (i) on geomagnetic latitude ( $\lambda$ ). Redrawn from HАмвACH \& KRUMSIEK (2000).

Abb. 3: Skizze des magnetischen Dipolfeldes der Erde mit normaler (a) bzw. inverser (b) Polarität. Der Stabmagnet im Erdmittelpunkt symbolisiert das axiale virtuelle Dipolmoment, den Hauptterm des EMFs. $\mathrm{Zu}$ beachten ist die Orientierung von magnetisch Süd und Nord. Weiterhin ist der Zusammenhang (Dipolformel, vergl. auch Abb. 2 (a)) von Inklination (i) und geographischer Breite ( $\lambda$ ) angegeben (nach HAMBACH \& KRUMSIEK, 2000).

tensity at the moment of formation of the rocks under investigation and to derive a chronology of temporal changes of these elements. This knowledge of the temporal geomagnetic field in the past offers chronometric possibilities on various geologic time scales. For chronological investigations, the use of quite short-lasting subchrons or even magnetic excursions is more effective than the use of chrons. In the following chapters, we will give examples and simple explanations for the use of the temporal change of elements of the geomagnetic field as dating tools in Quaternary research. In doing so, we will focus on examples from continental sedimentary archives and archaeomagnetic studies.
For a deepened insight on palaeomagnetism see, for example, Butler (1992) and on the temporal characteristics of the geomagnetic field we refer to ChAnNell et al. (2004a), GuBBINS (2008) and JACOBS (1994).

\section{Remanence acquisition}

All information carried by the main elements of the geomagnetic field described above can be stored in almost every rock type and up to ages of more than billions of years. The carriers of the magnetic memory in rocks are ferrimagnetic and antiferromagnetic minerals. These are iron minerals, exclusively iron oxides/hydroxides 
and sulphides, with special lattice properties that enable the storage of magnetic information over geological time at ambient temperature. For simplicity, we will call them magnetic minerals in the following (sensu strictu). We will give only a short introduction into the processes responsible for remanence acquisition. For a detailed description, we refer to the literature mentioned above (e.g., BUTLER 1992).

\subsection{Magmatic rocks}

In magmatic rocks, as well as in heated archaeological materials, a so-called thermoremanent magnetization (TRM) or thermoremanence carries the ancient signal of the EMF. A TRM is produced by cooling to temperatures below the Curie temperature (CT) in the presence of a magnetic field. The $\mathrm{CT}$ is a mineral specific temperature, generally lower than $700^{\circ} \mathrm{C}$, below which the minerals become magnetic. The TRM at surface temperature can be stable over geological time and resistant to magnetic fields after original cooling. Best long-term recorders are flood basalt provinces with long-lasting volcanic activity such as the Deccan traps in India (CourtiLlot et al. 1986) or volcanites on Gran Canaria (LeONHARDT et al. 2002). In case of rapid and frequent eruptions, it is even possible to record a complete change of polarity (LeOnhardT et. al. 2002; LeONHARDT \& Soffel 2002). A TRM can also be the result of a metamorphic overprint, if the reached temperatures and/or time spans are sufficient.

\subsection{Archaeological materials}

Because rapid cooling of lava flows takes place on time scales of hours to years, a lava flow provides a spot reading of the EMF elements, which is stored as the TRM. The same happens when a hearth, oven, kiln or any other artificially fired structure is heated and cooled down in the EMF. They will obtain a TRM parallel to the EMF. For soil, clay or loam, apart from detrital or diagenetic Fe-bearing minerals, new magnetic minerals are formed under the influence of fire and hence the magnetism of the material is consider- ably enhanced (LE Borgne 1955). The TRM carried by young lavas or archaeological material is normally very stable and only minor secondary magnetisation components are observed.

\subsection{Sediments}

Sediments are able to record information about the EMF by a depositional process called acquisition of post-depositional remanent magnetisation (PDRM). During deposition and diagenesis, detrital magnetic minerals may become aligned parallel to the EMF and the sediment acquires the primary PDRM. Most of the detrital minerals involved in this process acquired their primary magnetic moment by thermal processes and carry therefore a stable TRM. In comparison to the thermal remanent magnetisation described earlier, the PDRM is normally less intensive and stable (for fundamentals see e.g., Hamano (1980) and Tucker (1980)). There are several processes that may weaken the primary (quasi-synsedimentary) magnetisation, for example bioturbation, compaction or alteration of magnetic minerals by changing chemical environments. As described by several authors (e.g., BleIl \& vON DobeneCK 1999; Evans \& Heller 2003; Roberts \& WinKLHOFER 2004) the most effective handicap against recording of short lasting subchrons is the lock-in mechanism. This mechanism describes the fixing of the magnetic remanence in sediments. Remanence locking does not happen immediately during deposition at or near to the sediment water interface, but needs a specific amount of sediment (lock-in depth) superposed to force dewatering, which in turn hinders grain rotation. The required lock-in time in case of fine grained clastics varies depending on grain size and sedimentation rate and was found to be in the order of 150 years in lake sediments with high sedimentation rates (STOCKHAUSEN 1998). Due to this process, it may happen that the lock-in depth (height of sediment necessary to fix magnetic remanence) needs more time to be collected than a subchron lasts. In that case, such a subchron may be entirely suppressed or masked. This is even more valid for the shorter 
excursions of the magnetic field, which - if recorded and well dated - are excellent time markers.

The precipitation and growth of magnetic minerals during diagenesis and weathering is also an important process of remanence acquisition. This chemical process may lead to a stable so-called chemical remanent magnetisation (CRM). A CRM may occur in all kind of rocks at any time, if the environmental conditions are appropriate.

\section{Methods in palaeomagnetic dating}

Palaeomagnetic dating includes all approaches dealing with the temporal variation of the direction as well as with the intensity of the EMF on time scales from $10^{2}$ to $10^{7}$ years. On time scales of only a few million years, the wellknown temporal pattern of reversals of the EMF provides an excellent tool for the subdivision of sedimentary sequences as well as volcanic rocks. Short-lived changes of the EMF (in the order of $10^{3}$ years) in direction and intensity are called geomagnetic excursions, as stated above. If their chronology is known, they are perfect time markers, especially in sequences that are hardly datable by other methods. Records of the intensity variations of the EMF retrieved from sediments (relative palaeointensity), volcanic rocks and archaeological items (absolute palaeointensity) may also serve as dating tools and their application in stratigraphic studies is continuously increasing.

\subsection{Magnetic polarity stratigraphy}

Magnetic polarity stratigraphy or magnetostratigraphy is based on the temporal pattern of the reversals of the EMF as documented in the geomagnetic polarity timescale (GPTS). In the 1960s, it was found that sea floor spreading at mid-ocean ridges led to the characteristic bilateral symmetric 'stripes' of normal and reversed polarised oceanic crust. This pattern is measurable by ship based magnetometers and provides the basis for the GPTS (e.g., Cox et al. 1967). The GPTS serves as the main 'levelling rule' for the magnetic polarity stratigraphy from the recent back to the Early Jurassic (Fig. 4, 5).

Magnetic polarity stratigraphy is one of the excellent and independent tools (among others, e.g., oxygen isotope stratigraphy and orbitally tuned cyclo-stratigraphy) available for retrieving chronometric information, especially from sedimentary sequences. Magnetic polarity stratigraphy capitalises on the fact that the polarity of the EMF is recorded in rocks shortly after deposition. A distinction is drawn between chrons $\left(10^{5}-10^{7}\right.$ years duration) and subchrons $\left(10^{4}\right.$ $-10^{5}$ years long). The first four chrons are usually named after famous geomagnetists (Brunhes, Matuyama, Gauss, Gilbert) and subchrons are named after the geographic location of their first discovery (Jaramillo, Olduvai). Both chrons and subchrons are helpful time markers, if recorded and classifiable (CHANnell et al. 2004a, Fig. 5). The chronologic system used in magnetostratigraphy was determined simultaneously with its development. A GPTS (Fig. 5) labelled with names was originally based on magnetic remanence data from continental volcanic sequences dated with K-Ar ages and it is mainly used in investigations of Quaternary and Early Tertiary rocks (Cox et al. 1967; MANKINEN \& DALRYMPLE 1979). In contrast, a GPTS with a numerical system, based on the scheme used for labelling the marine magnetic anomalies, is used for roughly the last $160 \mathrm{Ma}$, the time span with substantial portions of oceanic crust remaining in ocean basins (CANDE \& KENT 1995). The magnetic field anomalies are interpreted to be due to reversals of the geomagnetic field as recorded in the rocks of the oceanic crust (Fig. 4). A more detailed discussion about the nomenclature and evolution of the different GPTSs in use can be found e.g. in JACOBS (1994), McElhinNy \& MCFADDEN (2000) or OpdyKe \& ChanNell (1996). Combining GPTS and Milankovitch climate cyclicity improved application and led to a powerful geochronometer called the astronomical polarity timescale (APTS). APTS has improved accuracy of chronology for the Pliocene and Pleistocene and is now even used for calibrating high-precision radiometric dating (e.g., BAssiNOT et al. 1994; KENT 1999). 
Marine Magnetic Anomalies
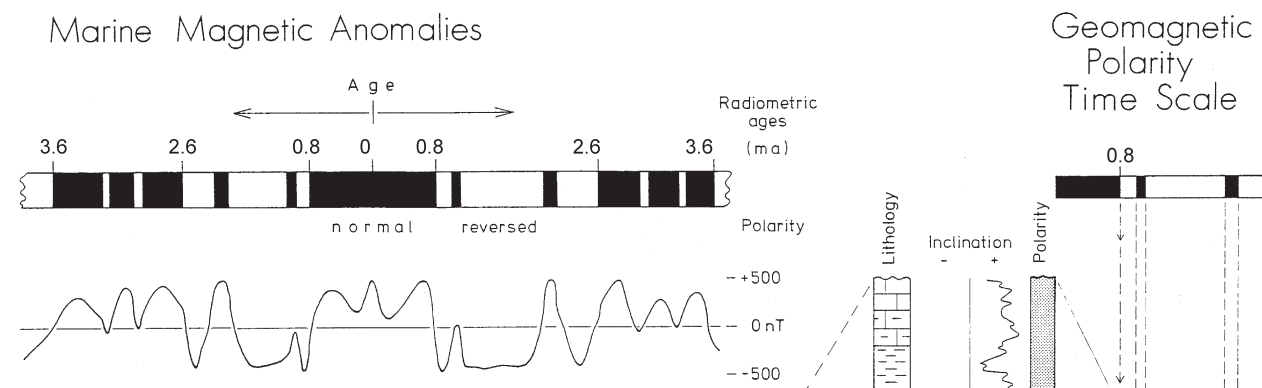

observed Magnetic Anomalies
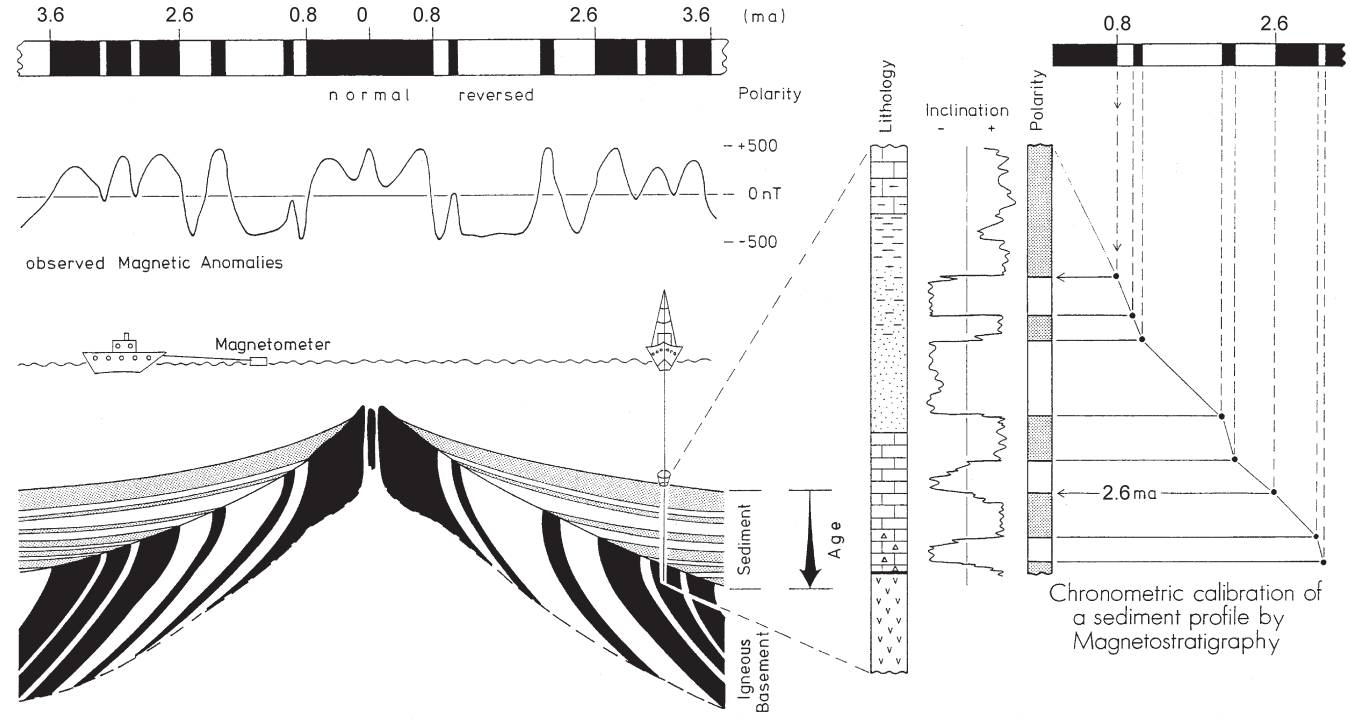

Fig. 4: Sea floor spreading at mid-ocean ridges leads to the characteristic bilateral symmetric 'stripes' of normal and reversed polarised oceanic crust. This pattern is measurable by ship-based magnetometers and provided the basis for the Geomagnetic Polarity Time Scale (GPTS). The GPTS serves as the 'levelling rule' for the magnetic polarity stratigraphy. From Hambach \& KRUMSIEK (2000).

Abb. 4: Die Bildung von neuem Ozeanboden (sea floor spreading) an den mittelozeanischen Rücken führt zu den charakteristischen, bilateralen, symmetrischen ,Streifen' von normal und invers magnetisierter ozeanischer Kruste. Dieses Muster wird mit Seemagnetik gemessen und lieferte die Basis für die geomagnetische Polaritätszeitskala (GPTS). Die Magnetostratigraphie benutzt die GPTS zur Kalibration der Zeit (aus HAMBACH \& KRUMSIEK, 2000).

\subsubsection{Magnetic polarity stratigraphy in sedimentary archives}

With respect to sediments, the situation is generally complex. Firstly, in limnic and marine sediments, conditions for recording the complete succession of changes in the EMF prevail frequently (ChANNELl 1999; CLEMENT \& Kent 1987; Frank et al. 2007; Nowaczyk et al. 1994), in contrast to fluvial continental sedimentation, which is very often far from being continuous. In their milestone publication about Chinese loess, Heller \& Liu (1982) were able to demonstrate the great potential of Quaternary continental sediments for magnetostratigraphy. This was the starting point for a great variety of studies in Quaternary sediments all over the world (e.g., LANGEREIS et al. 1997; Rolph 1993; RöSLER et al. 1997; Worm et al. 1998; see textbooks by Evans \& Heller 2003 and Opdyke \& Channell 1996). Secondly, remanence lock-in of sediments (see chapter 3.1) does not happen immediately after deposition but needs a specific amount of sediment superposed to force dewatering (e.g., BLEIL \& von Dobeneck 1999; Butler 1992; Evans \& Heller 2003; TAuXe 1998).

In the following, we will discuss some exemplary studies in which magnetic polarity stratigraphy was successfully applied to continental sediments. Though there have been many attempts to date Quaternary sediments 


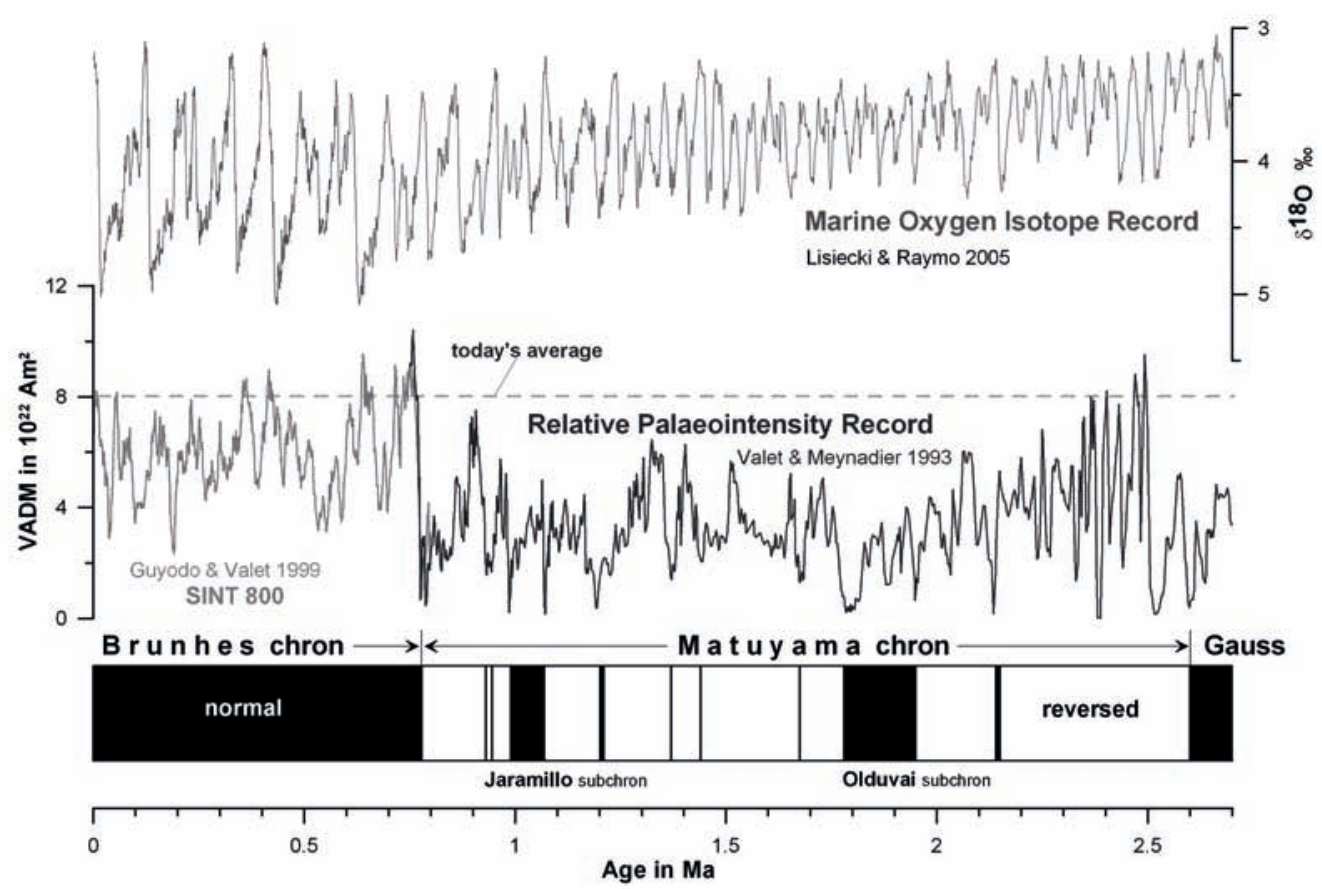

Fig. 5: The GPTS of the Quaternary is characterised by the normal Brunhes and the reversed Matuyama chron, of which the latter is interrupted by several subchrons. A record of Earth's magnetic axial dipole moment (VDAM) temporal variations is also shown. Note that the minima in RPI go together with polarity changes and that today's dipole moment is relatively high compared to most of the length of the Quaternary. The marine oxygen isotope record shows the evolution of the global ice volume and thus of the global climate. Data from Channell et al. (2004a) [GPTS], Valet \& Meynadier (1993) and Guyodo \& Valet (1999) [relative palaeointensity, RPI] and LISIECKI \& RAYMO (2005) [marine oxygen isotopes].

Abb. 5: Die GPTS des Quartärs unterteilt sich im Wesentlichen in die normale Brunhes- und die inverse Matuyama-Chrone, letztere ist von mehreren Subchronen unterbrochen. Eine Kurve der zeitlichen Änderung des Dipolmoments der Erde ist ebenfalls dargestellt. Man beachte das zeitgleiche Auftreten von Polaritätswechseln und Minima des Dipolmoments. Weiterhin beachtenswert ist die Stärke des heutigen Dipolmoments der Erde im Vergleich zu der während des Quartärs. Die marine Sauerstoffisotopenkurve zeigt die Entwicklung der globalen Eisvolumina und somit des globalen Klimas. Daten von Channell et al. (2004a) [GPTS], VAlet \& Meynadier (1993) und Guyodo \& VAlet (1999) [relative Paläointensität, RPI] and LisiecKi \& RAYMo (2005) [marine oxygen isotopes].

by palaeomagnetic methods in the last decades, the success story of magnetic polarity dating in continental Quaternary sequences started with the seminal work of Friedrich Heller and TungSheng Liu assigning the Chinese loess to the Quaternary time table and correlating it with the global ice volume record (HeLler \& LiU 1982, 1984). For further reading we refer to Evans \& Heller (2003) and Heller \& Evans (1996).

In active orogenic belts such as the Alpine range, sedimentary sequences very often reveal only incomplete records representing short time intervals. Even though a polarity change is identified, due to the indistinguishability of magnetic polarity patterns for the last 3 million years (mainly because of negligible small tectonic movements of the European plate) the acquired data cannot be unambiguously assigned to any interval of the GPTS without further chronological information. Magnetic polarity stratigraphy on glacial sediments of the IllerLech-Platte showed problems in determination 
of palaeodirections for these sediments carrying a remanence of weak intensity and difficulties on stratigraphic interpretation due to incompleteness of the profiles. However, it was possible to find the Matuyama-Brunhes boundary in two profiles on the Zusam gravel plain and to date it to older than $780 \mathrm{ka}$ (STRATTNER \& Rolf 1995).

Worm et al. (1998) studied a more than $4 \mathrm{~km}$ thick succession of delta sediments from Bangladesh that was devoid of firm dating through biostratigraphy or other methods. Applying classical magnetic polarity stratigraphy, a Lower Pleistocene to Lower Pliocene age could be assigned for the whole sequence. This new and reliable age model inferred a sedimentation rate of $1.2 \mathrm{~m} \mathrm{ka}^{-1}$, which appears to be one of the highest sedimentation rates in Earth history that was sustained for millions of years.

Pleistocene fluvial sequences in the eastern part of the Pannonian Basin were studied in order to establish a palaeoclimatic framework for the region (NADOR et al. 2003). Magnetostratigraphy indicates that the sediment sequences span the last 2.6 Ma without significant hiatuses (COOKE et al. 1979). Comparison of systematic variations in magnetic susceptibility with changes in grain size distribution revealed Milankovitch-scale cyclicity in sedimentation. Comparison of pollen and gastropod paleoecological data with the magnetic susceptibility proxies suggests that climate was a major allogenic control factor on the cyclicity. This study convincingly demonstrates the potential of magnetic dating techniques even in fluvial sequences, which are important palaeoclimate archives on the continents.

The Quaternary stratigraphy of the North Sea and surrounding areas received essential support through magnetostratigraphic investigations. Maher \& Hallam (2005) were able to determine stable magnetic polarities from discontinuous sediment sequences, of Plio/ Pleistocene age, occurring onshore around the southern North Sea margins. The reliable palaeomagnetic polarity determinations were used, in combination with biostratigraphic data and in comparison with the GPTS, to ascribe correlations and absolute ages, which shed a new light, especially on the Quaternary stratigraphy of East Anglia.

The lower Rhine Embayment and the RhineMeuse-Delta in the Netherlands are complex sedimentary systems which recorded environmental changes of the Rhine catchment including even parts of the Alps (Preusser 2008). Their chronology is largely based on magnetostratigraphic studies (e.g. BoENIGK \& FRECHEN 2005; ZAGWIJN 1992), which provide the only time constraints especially for the Lower Pleistocene.

Magnetostratigraphic and rock magnetic investigations performed on fluvial sediments from the Ludwigshafen-Parkinsel drilling project (Upper Rhine Graben (URG), Germany) show the change from mainly locally controlled sedimentation from the graben margins to a more distinct alpine controlled sedimentation at a depth of $177 \mathrm{~m}$ by magnetic data (Rolf et al. 2008). Based on lithostratigraphic correlation with other sedimentary records from the URG and also based on palynological evidence, this event happened at the end of the Late Pliocene at the top of a normally polarised core interval (end of the Gauss Chron?). The well documented characteristic change in magnetomineralogy from goethite to greigite almost at the same stratigraphic level, was interpreted solely as a climatic signal, which can be correlated with the global climate change at $\sim 2.6$ Ma that is well documented in a wide range of sedimentary environments (e.g. deep-sea sediments, loess).

The chronology of early humans in Europe is intrinsically tied to the results of palaeomagnetic investigations at the excavation sites. From Dmanisi, Georgia, several findings of Homo erectus are reported from sediments containing a reversal and resting on normally polarised basalt. Supported by the faunal context, an age slightly younger than the Olduvai subchron was inferred making these human remains from Dmanisi the oldest in Eurasia (Gabunia et al. 2000). At Atapuerca, Spain, human remains (Homo erectus?) were found in cave debris that are reversely polarised. Combined bio- and magnetostratigraphy prove here 
the existence of early humans already well before the Matuyama-Brunhes boundary (PARES \& Perez-Gonzalez 1995). Also, the age of the earliest "German", the Homo heidelbergensis was constrained by palaeomagnetism. The investigation of several sedimentary units above and below the sand beds in which the jaw was found exhibit only normal polarity, assigning this beds doubtless to the Brunhes chron (HAMBACH et al. 1992; WAGNER et al. 1997).

\subsubsection{Magnetic polarity dating of magmatic rocks}

Volcanic rocks are normally stable and firm recorders of the EMF. Yet due to the relatively short duration of volcanic activities compared to quasi-continuous recorders such as sediments, the magnetic information very often only represents spot-readings of the EMF and shorter reversals were frequently not recorded. If by chance a volcano was active during the life-time of an excursion or subchron, it might be possible to identify them (see chapter 4.1.3).

The volcanic oceanic crust represents by far the most important archive for the history of the EMF, going back to about $160 \mathrm{Ma}$ at least. Sea floor spreading at mid-ocean ridges led to the characteristic bilateral symmetric 'stripes' of normal and reversed polarised oceanic crust. This pattern is measurable by ship-based magnetometers and provided the basis for the Geomagnetic Polarity Time Scale (GPTS) (Fig. 4). The GPTS serves as the 'levelling rule' for the magnetic polarity stratigraphy and its development started in the sixties of the last century. The beginning, however, was the work of Allen Cox who systematically measured volcanic rocks, which were dated by the contemporaneously improved K-Ar dating techniques. His early GPTS covered only the last $5 \mathrm{Ma}$, but allowed the determination of spreading rates, which in turn lead to the extrapolation of the GPTS back to the Early Jurassic (Cox et al. 1967; Opdyke \& Channell 1996).

There are numerous magnetostratigraphic studies of volcanic sequences on continents. We would like to highlight the extensive work that was done on the Deccan traps in India (CouRTILLOT et al. 1986). Only magnetic polarity was able to prove the unexpected short eruption interval for this immense amount of lava. In only about $1 \mathrm{Ma}$, exactly around the Cretaceous-Tertiary boundary, the complete succession of trap basalts were erupted and possibly contributed to the vast extinction event at the end of the Mesozoic.

LEONHARDT et al. (2002) studied a continuous series of 87 lava flows from the mid-Miocene shield basalts of Gran Canaria. The sequence covers a reversal of the EMF from reverse to normal. Intermediate directions of the field are recorded in 34 lava flows and in addition to the reversal, three excursions (see chapter 4.1.3) are recorded. The results impressively demonstrate the potential of magnetic polarity studies for temporally highly resolved volcanic sequences and their relevance for understanding the processes controlling the geodynamo. Conventional K-Ar dating techniques are unable to resolve short-lived volcanic events and very often suggest continuous volcanic activity in a given time span. Palaeomagnetic data from the Quaternary alkali basaltic volcanic field of the Perşani Mountains, Romania, revealed sites with normal, transitional (excursional) and reversed polarity (Fig. 6). The combination of $\mathrm{K}$-Ar dating with palaeomagnetic polarity determinations allowed the discrimination of short-lived volcanic phases of only a few thousand years duration, well beyond the precision of K-Ar dating (PANAiotu et al. 2004).

\subsubsection{Geomagnetic Excursions as time markers}

As discussed above, the shape of the EMF varies on time scales ranging from days to tens of millions of years. Long periodic amplitudinal and directional variations as polarity changes and even polarity transitions, as well as medium to long periodic secular variations (see chapter 4.2) are relatively well-known phenomena (MERRILL et al. 1996). However, prominent short-lived features $(<5 \mathrm{ka})$ such as magnetic polarity episodes and reversal excursions are only rarely 


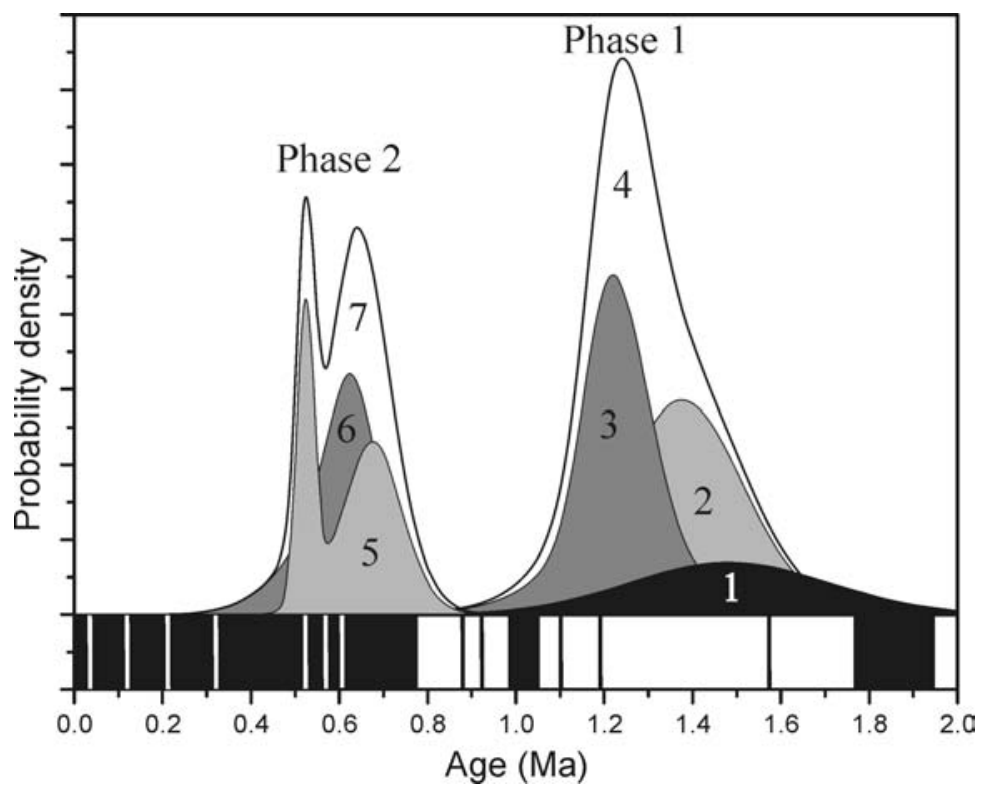

Fig. 6: Distribution of K-Ar ages from the Perşani Mountains, Romania. This alkali basaltic volcanic field revealed sites with normal, transitional (excursional) and reversed polarity. The individual density distributions display populations of normal, transitional (excursional) and reversed polarity sites separated (1-3, 5-6) and combined $(4,7)$. The combination of $\mathrm{K}$-Ar dating with palaeomagnetic polarity determinations allows the discrimination of short-lived volcanic phases of only a few thousand years duration, well beyond the precision of K-Ar dating. Thin white and black bands are short lived polarity excursions (white) or subchrons (black, Matuyama). From Panaiotu et al. (2004).

Abb. 6: Verteilung der K-Ar-Alter der Perşani Berge, Rumänien. Dieses alkalibasaltische Vulkanfeld enthält Vulkanite mit normaler, transitionaler (exkursionaler) und inverser Polarität. Die Verteilungen zeigen Populationen mit normaler, transitionaler (exkursionaler) und inverser Polarität im Einzelnen (1-3, 5-6) bzw. die Gesamtverteilungen $(4,7)$. Die Kombination von K-Ar-Altern und der Bestimmung der magnetischen Polarität erlaubt die Unterscheidung von kurzen vulkanischen Phasen mit nur einigen Tausend Jahren Dauer, die durch die K-Ar-Datierung allein nicht aufgelöst werden können. Schmale weiße und schwarze Bänder sind kurzlebige Polaritätsexkursionen (weiß) oder Subchrons (schwarz, Matuyama). Aus PANAIOTu et al. (2004).

documented. These rare features of the EMF, socalled geomagnetic events, are characterised by large deviations from the dipole direction often associated with a low relative palaeointensity. Most of them are found in the Brunhes chron (since $780 \mathrm{ka}$ ago) where several have been documented in sedimentary and volcanic rocks. The reports include short-term reversals, which probably occur globally (e.g. Blake polarity episode), and reversal excursions whose extension is possibly regionally restricted (e.g. Fram Strait episode?). The significance and interpretation of geomagnetic events, and to a certain extent even their interpretation as real manifestations of the EMF, is still open to debate (LAJ \& CHANNELL, 2007). Geomagnetic excursions probably originate from incomplete reversals that employ only a polarity change in the liquid outer, but not in the solid inner core (GubBins 1999). Thus, the older picture of the geomagnetic field having long periods of stable polarity may not be correct; instead, the field appears to suffer many dramatic changes in direction and reduction in intensity.

The most significant progress in our understanding of temporal variations of the EMF 
(A)

Langereis et al. (1997)

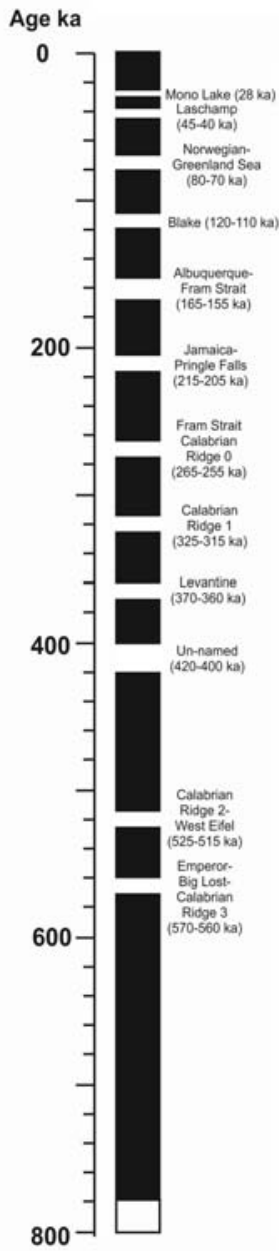

(B)

\section{ODP Site 1062 \\ Lund et al. \\ (2006)}

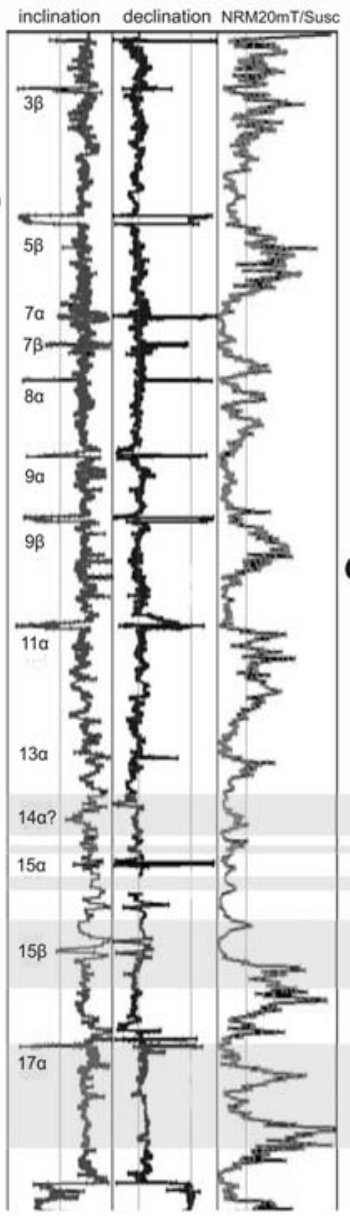

(D)

(E)

\section{SINT $800 \quad$ GITS ${ }^{40} \mathrm{Ar} /{ }^{30} \mathrm{Ar}$ Guyodo \& Valet Singer et al. (1999) \\ (2008)}

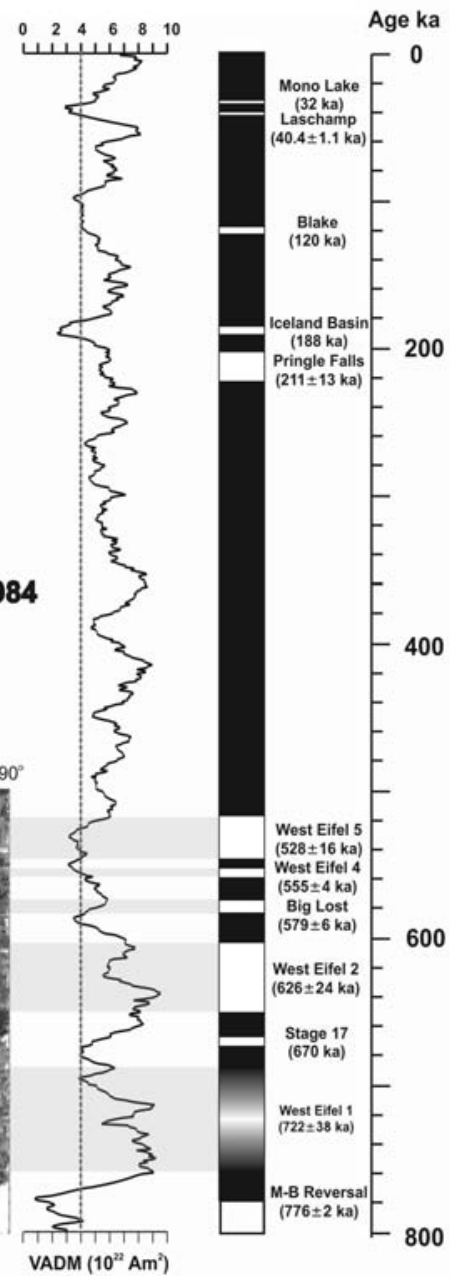

Fig. 7: Records of geomagnetic excursions and palaeointensity during the Brunhes Chron. Records are from: A) Langereis et al. (1997), B) Lund et al. (2006), C) Channell et al. (2004b), D) Guyodo \& Valet (1999), and E) Geomagnetic Instability Time Scale (GITS) based on ${ }^{40} \mathrm{Ar} /{ }^{39} \mathrm{Ar}$ dated volcanic rocks plus excursions in marine sediment cores that have been dated via continuous oxygen isotope-based astrochronology (e.g. Channell et al. 2004a). Redrawn from Singer et al. (2008).

Abb. 7: Aufzeichnungen der geomagnetischen Exkursionen während der Brunhes-Chron. Die Kurven stammen von: A) Langereis et al. (1997), B) Lund et al. (2006), C) Channell et al. (2004b), D) GuYodo \& Valet (1999), und E) Geomagnetische Instabilitätszeitskala (GITS) basierend auf ${ }^{40} \mathrm{Ar} /{ }^{39} \mathrm{Ar}$ datierten vulkanischen Gesteinen und Exkursionen aufgezeichnet in marinen Sedimentkernen, die mit einer kontinuierlichen astrochronologischen Sauerstoffisotopenkurve datiert wurden (z.B. ChAnNell et al. 2004a). Nach Singer et al. (2008). 
during the last decade stems from marine sedimentary records. This comes from relative palaeointensity curves in particular (see chapter 4.3), but some directional records also suggest that the processes that generate the EMF are highly dynamic and that temporal variations occur on a much shorter time scale than previously thought possible (GUYODO \& VALET 1999; Lund et al. 2006; NowaczyK et al. 1994). However, while changes of the virtual axial dipole moment (VADM) account for the global nature of apparently most of the (relative) minima of the relative palaeointensity variations, not all geomagnetic events or excursions in the Brunhes chron could be traced globally (Fig. 7).

Nevertheless, combined evidence suggest that at least 10 polarity events or excursions exist in the Brunhes chron, which are often not primarily preserved and / or diagenetically overprinted in most of sedimentary environments due to the palaeoclimatic conditions under which they were recorded (e.g., BleIL \& vON DoBENECK 1999; LANGereis et al. 1997). However, an impressive record of well documented excursions has been published in the last years. LANGEREIS et al. (1997) gave a thorough review of Brunhes age excursions and reported several new ones from a detailed study of an eastern Mediterranean piston core. Precisely calibrated astronomical reversal boundaries and ages for shortlived subchrons and polarity episodes in the Matuyama chron were published by HoRNG et al. (2002). The Ocean Drilling Program (ODP) recovered many long sediment sequences from around the world that contain medium- to highresolution paleomagnetic records of Brunhes ages. Lund et al. (2006) collected the evidence for 17 excursions younger than the last reversal from these records and provided accurate ages based on oxygen isotope chronostratigraphies. From a marine core off Portugal going back to $400 \mathrm{ka}$, Thouveny et al. (2004) documented eight lows in relative palaeointensity. Four of these lows mark already well-known events and were also accompanied by directional excursions, which points to their global nature. From the ODP site 919, located in the Northern Atlantic, ChanNell (2006) found additional ev- idence for four already well documented excursions of the last $250 \mathrm{ka}$. This interval contains at least five polarity episodes with global evidence. From young to old these are: Mono Lake (32$34 \mathrm{ka})$, Laschamp (40-42 ka), Blake (115-120 $\mathrm{ka})$, Icelandic Basin ( 185 ka) and Pringle Falls (205-225 ka) (ChANNell 2006). In recent years, Brad Singer pointed out the instability of the dominant normal polarity of the Brunhes chron. Singer and his co-workers applied precise ${ }^{40} \mathrm{Ar} /$ ${ }^{39} \mathrm{Ar}$ isochron dating on volcanic rocks containing excursional palaeomagnetic records. Combining their data with records from sediments, they constructed a Geomagnetic Instability Time Scale (GITS) for the Brunhes Chron (Singer et al. 2008, Fig. 7).

Geomagnetic excursions have even been reported from loess profiles. The earliest evidence dates back to the seventies and was later confirmed by numerous papers published in the mid 1990s (e.g., Reinders \& Hambach 1995, and references therein; Evans \& Heller 2001, for review and further reading). Recently, PILIPENKo et al. (2006) and ZHU et al. (2006) presented records containing excursional directions from loess sections in the Ukraine and the Chinese loess plateau, proving that even loess units can record short-term features of the EMF.

We will not provide any listing of Brunhes excursions that could be useful stratigraphic markers, because their exact ages and timing as well as their global or only regional nature are still under debate. Therefore, we would like to draw the reader's attention to some recently published papers (e.g., Channell 2006; Lund et al. 2006; SINGER et al. 2008) and we encourage them to follow the forthcoming relevant publications.

In the context of geomagnetic excursions, the possible link between climate and EMF is being increasingly addressed. Already WORM (1997) suggested "a link between geomagnetic reversals and events and glaciations" following the observation of a concomitant incidence of geomagnetic polarity events and sediments indicating periods of cold climate. The occurrence of excursions and reversals with the obliquity signal of the Earth's orbit was tested by Fuller (2006). His results have shown that 
the strongest minima in the palaeomagnetic intensity records correlate with obliquity minima and suggest that precession provides some power to the geodynamo. In their study of a well dated marine core off Portugal, THOUVENY et al. (2004) made the interesting observation that relative palaeointensity lows often coincide with the end of interglacial or interstadial stages. They found, furthermore, a dominant period in the relative palaeointensity record of about $100 \mathrm{ka}$ and a phase shift between the $\delta^{18} \mathrm{O}$ and the relative palaeointensity record in the order of $18 \mathrm{ka}$. Both findings may suggest the dependence of Earth's climate system and EMF upon the same driving process.

However, possible interactions between the Earth's climate system, the geodynamo and solar activity can presently not be proven. Further evidence and models have to be awaited. The papers of Courtillot et al. (2007) and FulLER (2006) give an up-to-date summary of the current state of discussion.

\subsection{Secular variation}

The shortest with palaeomagnetic techniques resolvable temporal variation of the EMF is a lower angular variation $\left(10-30^{\circ}\right)$ called secular variation (SV) occurring on time scales from 1 to $10^{3}$ years. The SV of the EMF provides insight into processes in the outer liquid core of the Earth. Therefore, considerable effort has been undertaken to map the palaeomagnetic SV with high temporal resolution over long timeintervals from sites all over the world (e.g., Lund 1996; Stockhausen 1998). However, even for a relatively large area such as Europe, only few records exist that are considerable longer than the Holocene, or extend into the early Upper Pleistocene (BRANDT et al. 1999; ThOuvEny et al. 1990).

SV is observed today by magnetic observatories, which are spread over the globe as well as by satellites, i.e. CHAMP or OERSTEDT (OlsEn et al. 2006). Historic measurements of SV go back in time only 400 years (JACKSON et al. 2000), whereas archaeomagnetic data cover the past two or three millennia for Europe (DE
Marco et al. 2008a; Gallet et al. 2002; GómezPaccard et al. 2006a, b; MÁrton \& Ferencz 2006; Schnepr \& Lanos 2005, 2006; Tema et al. 2006; ZANANIRI et al. 2007) and for America (Bowles et al. 2002, Sternberg 1989) and go back about 8000 years for a few places, i.e. Bulgaria (Kovacheva et al. 1998) (Fig. 9). Secular variation master curves have been obtained from many places on Earth with a broad range of time resolution and directional fidelity. An overview of the data sets obtained for the past 7000 years was given by (KorTe et al. 2005). Well-defined archaeomagnetic secular variation curves have time resolutions in the order of 50-100 years. $\mathrm{SV}$ data from sediments often cover much longer time intervals, but here the time resolution as well as preciseness of the direction is lower (Fig. 8). While the so-called archaeomagnetic dating, which is also possible for lavas (TANGUY et al. 2003), provides a date with error margins (LANOs 2004; LE GoFf et al. 2002), SV dating for lake sediments uses wiggle matching in order to correlate sedimentary profiles.

\subsubsection{Dating with secular variation}

Dating with secular variation (SV) is possible on time scales from decades to millennia for the past $50 \mathrm{ka}$. It can be applied to young volcanic rocks, lake sediments with high sedimentation rates, baked in-situ archaeological structures and, with limitations, to displaced ceramic material.

The dating process depends strongly on the material to be dated. Continuous data series obtained from sediments require wiggle matching techniques in order to replace depth by a time scale calibrated with SV patterns, whereas in contrast, volcanic rocks or archaeological materials provide spot readings of the direction (intensity), which allow calculation of a probability distribution of age, but does not necessarily provide a single date.

\subsubsection{Archaeomagnetic dating}

Archaeomagnetic dating uses detailed regional calibration curves with an error envelope (Fig. 


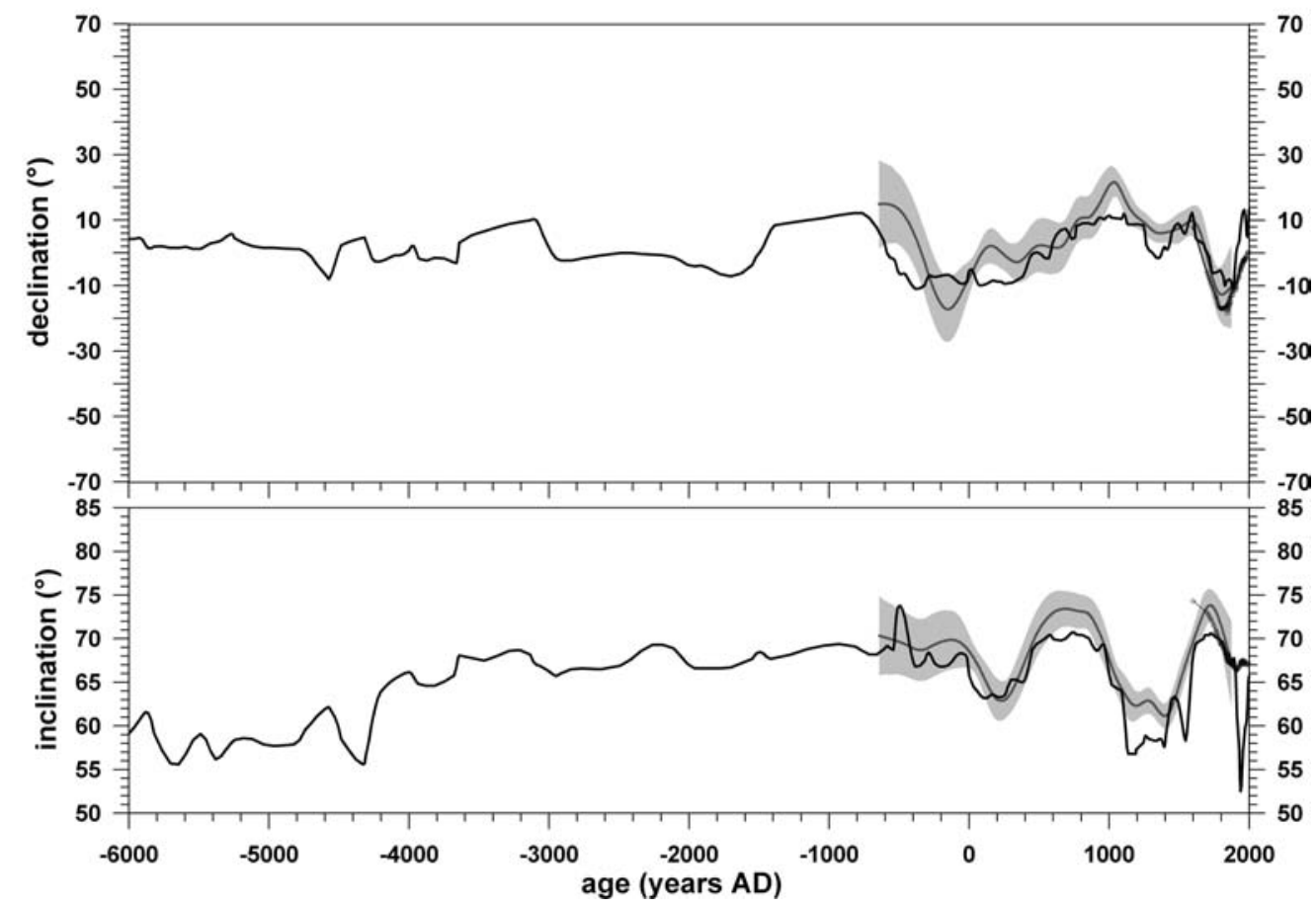

Fig. 8: Declination and inclination (black curves) for the past 6000 years obtained from paleomagnetic measurements of the Holzmaar sediments (STOCKHAUSEN 1998). The curves are shown in comparison with the German archaeomagnetic secular variation curve (SCHNEPP \& LANOs 2005, see also Fig. 9, grey curves with $95 \%$ error envelope). In order to match the variation pattern, the time scale of the sediment curve was shifted by 125 years to younger dates.

Abb. 8: Deklination und Inklination (schwarze Kurven) der vergangenen 6000 Jahre, die aus paläomagnetischen Untersuchungen der Holzmaarsedimente gewonnen wurden (STOCKHAUSEN 1998). Die Kurven sind im Vergleich mit der deutschen archäomagnetischen Säkularvariationskurve (SCHNEPP \& LANOs 2005, siehe auch Abb. 9, graue Kurven mit 95\% Fehlerband) gezeigt. Damit die Variationsmuster der Sediment- und der archäomagnetischen Kurven zusammenpassen, wurde die Sedimentkurve um 125 Jahre zu jüngeren Altern hin verschoben.

8). This dating compares directions and intensities of unknown age against the curves and a probability distribution of age is obtained. Additional constraints (archaeological finds, stratigraphy) allow a reduction in ambiguity. Archaeomagnetic dating can be applied to insitu fired structures and, with limitations, also to displaced material as potsherds or bricks. Whereas the polarity time scale is valid for the complete Earth, because a polarity reversal is a worldwide phenomenon, secular variations show regional patterns that cannot be transferred over very far distances (CASAS \&
INCORONATO 2007). Accordingly, a reference curve is required, which is valid for the region in which the archaeological structure was found or in which the displaced material was produced; for archaeomagnetic dating applications. Reference curves must be established first by studying the direction and/or intensity of well dated archaeological material for a certain region, before archaeomagnetic dating is possible (e.g., De MARco et al. 2008b).

Due to the lock-in mechanism in sediments mentioned above, a shift between archaeomagnetic SV variation curves and sedimentary 
secular variation curves is observed, which has to be taken into account, if time resolutions below 500 years are required.

Besides archaeomagnetic reference curves, which are made for dating in specific regions, global models of the EMF are available (KORTE \& Constable 2005; Korte et al. 2005), which allow the calculation of secular variation curves for any place. The use of such model curves for dating purposes results in very uncertain ages. This has to be avoided for all regions from which no or only few data exist for the requested time interval.

\subsubsection{Secular variation dating in sedimentary archives}

In limnic and marine sediments, conditions for recording the complete succession of temporal changes of the EMF prevail frequently over diagenesis and other secondary processes. Normally, two questions are addressed before a palaeomagnetic record is analysed with respect to the underlying physical processes. Firstly, the crucial determination of a depth to time transformation to construct a well-defined time-series usually requires a multi-disciplinary approach, and several years, too. The second question addresses the nature of the record: how and when was the natural remanent magnetisation acquired; is it contemporaneous with the sedimentary matrix? If not, what is the time lag between sedimentation and remanence acquisition? In other words: is it possible to verify that a geological archive carries a record of the past variations of the EMF? Conventional techniques such as the stacking of multiple data from one lake (sedimentary environment) are used for such an evaluation. Supplementary arguments are then drawn from rock magnetic studies to construct plausibility arguments as to the origin of the stacked signal.

Warved sediments from the Eifel Maar lakes have been successfully used to retrieve reliable SV records for geomagnetic as well as for stratigraphic studies. The best record of the Holocene SV for Central Europe was derived from a thorough study of three Maar lakes from the
West-Eifel (Germany) (STOCKHAUSEN 1998, see Fig. 8). ZolitschKa et al. (2000) applied multiple dating methods and interlake comparison in order to establish a robust chronology for a Late Weichselian continental paleoclimate record from the Eifel Maar Lakes. Dating by means of SV serves here for the chronostratigraphic frame especially for the older part (10 $-23 \mathrm{ka}$ ) of the succession.

REINDERS et al. (submitted) presented the so far "oldest" SV record for Germany from cores of the dry Maar Jungfernweiher in the southern West Eifel Volcanic Field. The record covers the time interval from approx. $60-100 \mathrm{ka}$ and revealed a time interval of low SV which could be used to correlate the record to the SV records of Lac du Bouchet in Central France as well as to Lago Grande de Montichio in South Italy by wiggle matching (BRANDT et al. 1999; Thouveny et al. 1990).

\subsection{Dating by means of relative palaeointensity records}

Not only the direction, but also the intensity of the EMF at a given point at the Earth's surface provides important information about the EMF itself. As the direction, the intensity also undergoes temporal variations. During a polarity reversal, the intensity goes down, probably to less than $10 \%$ of the average values before or after the reversal (e.g., JACOBS 1994). The EMF also weakens dramatically (Fig. 5 and 7) during geomagnetic excursions (see chapter 4.1.3). The variation of the EMF intensity within the Brunhes normal chron is quite well-known and provides a tool for relative stratigraphic dating. Absolute palaeointensity can be determined from magmatic rocks as well as from heated archaeological materials by simulating the remanence acquisition process in the laboratory (e.g., Schnepp \& Hradetzky, 1994). In sediments, however, only a relative approximation for the intensity of the EMF at the time shortly after deposition is possible. For this purpose, the determined magnetic remanence is normalised by a measure for the concentration of magnetisable minerals in the sediment (TAUXE 




Fig. 9: Declination and inclination for archaeomagnetic secular variation reference curves are plotted versus time for several European countries: United Kingdom (UK, ZananiRI et al. 2007), France (FR) and Spain (ES, Gómez-Paccard et al., 2006a, b), Germany (DE, Schnepp \& Lanos 2005), Austria (AT, Schnepp \& Lanos 2006), Italy (IT, Tema et al. 2006), Bulgaria (BG, LAnos 2004) and Greece (GR, De Marco et al., 2008a).

Abb. 9: Deklination und Inklination aufgetragen gegen die Zeit der archäomagnetischen Säkularvariationsreferenzkurven für verschiedenen europäische Länder: Vereinigtes Königreich (UK, ZANANIRI et al. 2007), Frankreich (FR) und Spanien (ES, GómEz-PACCARD et al. 2006a, b), Deutschland (DE, Schnepp \& Lanos 2005), Österreich (AT, Schnepp \& Lanos 2006), Italien (IT, Tema et al. 2006), Bulgarien (BG, Lanos 2004), und Griechenland (GR, DE MARCo et al. 2008a).

1998). The result is a relative palaeointensity (RPI) record that shows variations in the order of ten thousands to thousands of years (Fig. 5). VALET \& MEYNADIER (1993) published one of the first long RPI records, which goes back 4 Ma and covers the whole Quaternary. For the past 800 ka, Guoyodo \& VALET (1999) built a stack of globally distributed marine RPI records. This synthetic intensity record (SINT $800)$ is the best 'master curve' presently available on this timescale (Fig. 5). Short-lived variations in SINT 800, however, seem to be suppressed due to the stacking process. A very detailed data set with high temporal resolution covering the last $75 \mathrm{ka}$ for the North Atlantic realm (North Atlantic PalaeoIntensity Stack, NAPIS) was published by LAJ et al. (2000) and was extended later on to a global stack (Global PalaeoIntensity Stack, GLOPIS, LAJ et al. 2004). High-resolution reconstruction of cosmogenic nuclide concentrations along sedimentary archives is an alternative approach for documenting past magnetic field changes. This approach is being increasingly applied in the study of marine as well as ice cores (e.g. CARCAILlet et al. 2004).

Recent studies of high-resolution RPI records from European loess sites contain evidence for multiple RPI lows between approximately 22 and $45 \mathrm{ka}$, including the "Mono Lake" and 


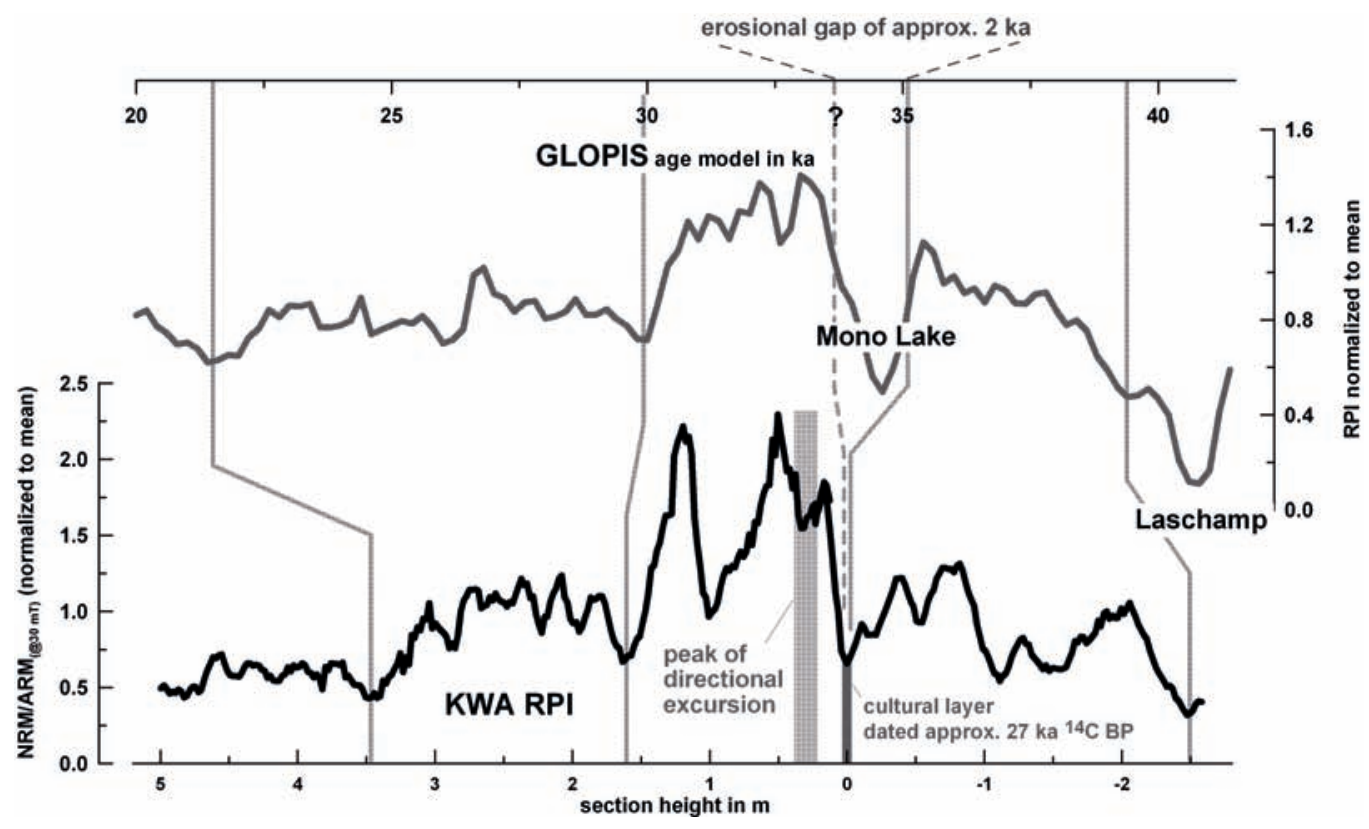

Fig. 10: A relative palaeointensity (RPI) record from a loess section in Krems (Lower Austria) and the Global Palaeointensity stack (GLOPIS). The Mono Lake and Laschamp geomagnetic excursions are characterised by pronounced intensity lows. Age (GLOPIS) and depth (from left: shallow, young to right: deep, old) are plotted on the abscissa vs. the RPI. Light grey lines indicate suggested correlations; a cultural layer dated by radiocarbon is indicated. From HamBACH et al. (submitted).

Abb. 10: Die relative Paläointensität (RPI) gemessen an einem Lössprofil aus Krems (Niederösterreich) und der Global Palaeointensity stack (GLOPIS). Die geomagnetische Mono-Lake- und die Laschamp-Exkursion werden durch deutlich hervortretende Abschwächungen der Intensität charakterisiert. Alter (GLOPIS) bzw. Tiefe (von links (jung bzw. hangend) nach rechts (alt bzw. liegend)) sind auf der Abszisse gegen die RPI abgetragen. Hellgrau gestrichelte Linien verbinden die vorgeschlagene Korrelation der Kurven; eine mit Radiokohlenstoff datierte Kulturschicht ist angegeben. Aus HamBACH et al. (submitted).

"Laschamp" geomagnetic excursions. The best documented RPI record stems from an archaeological site in Krems (Austria). The age model is based on AMS radiocarbon dates from cultural layers as well as on optical stimulated luminescence dating and RPI correlation to the GLOPIS stack. The investigation of the palaeomagnetic signal resulted in a reliable and comparable RPI record (Fig. 10). This highresolution palaeomagnetic record clearly emphasises the yet largely undiscovered but high potential of quasi-continuously deposited loess sites, which contain archaeological materials for palaeomagnetic studies (HAMBACH et al. submitted; ZEEDEN et al. 2008).

\section{Magnetic susceptibility stratigraphy}

Nowadays, magnetic properties of sediments and soils are widely used in Quaternary palaeoclimatic, as well as in geoarchaeological, research to characterise the palaeoenvironment and to indirectly date sedimentary sequences. Magnetic property variations with depth/time in sedimentary sequences are mainly climatically controlled and therefore can serve as relative dating tools if the timing of palaeoclimatic variations is known independently.

Palaeomagnetism and enviromagnetism use the same physical methods and similar technologies, but deal with fundamentally differ- 
ent phenomena. Palaeomagnetism is based on the fact that rocks can provide a record of the temporal variations of the EMF: Sediments may be regarded in this case as 'tape recorders' of the past EMF which we can decipher with palaeomagnetic methods. By knowing its temporal variations, one can indirectly date these sediments while correlating their records with 'master curves' (e.g., Butler 1992, Schnepp et al. 2004).

Enviromagnetism, the magnetism of sediments and soils (rock and mineral magnetism applied to environmental questions), however, describes the occurrence, abundance and properties of iron-bearing minerals in the environment: When we study the magnetic properties of sediments and soils as proxies for environmental change, we study the physical (magnetic) properties of the 'tape' itself and not the 'music', which is recorded on it (e.g., Evans \& Heller 2003).

Magnetic grains, exclusively iron oxides/ hydroxides and sulphides, occur virtually ubiquitously in Quaternary sediments, soils, dusts and organisms, albeit often in minor or trace concentrations. After sedimentation or reworking, they undergo diagenesis and pedogenesis when, for example, more humid conditions predominate, which is reflected in physicalchemical alterations of the sediment or soil. These alterations can also result in transformation, depletion as well as enhancement of magnetic minerals. Especially ferrimagnetic minerals react in ambient laboratory magnetic fields (measurement of magnetic susceptibility, MS) several orders of magnitude more strongly than other iron-bearing minerals. Thus, already very small amounts of magnetic minerals control the magnetic properties of sediments or soils. Furthermore, they may act as sensitive magnetic recorders of palaeoclimatic and palaeoenvironmental change. Changes in climate as well as human occupations produce changes in the environment, including sedimentary and soil-forming environments. Thus, magnetic information from a wide range of marine as well as continental sedimentary archives reflects alternating warm/humid and cold/dry climates during the Quaternary.
Therefore, MS and other magnetic parameters as functions of depth in sedimentary archives can serve as proxies for palaeoclimatic variations also on the continents and allow for a close match with the isotope records from Greenland and Antarctic ice cores as well as with all kinds of high-resolution palaeoclimatic archives on millennial scales.

Loess is by far the most important terrestrial archive that provides detailed palaeoclimatic information for the whole Quaternary and in China goes back to even the Pliocene. Heller \& LiU (1984) first used magnetic susceptibility variations in Chinese loess to correlate the loess deposits to marine records. The MS variations in the loess-palaeosol couplets in the Chinese loess plateau resemble the pattern of the global ice volume record with higher values in palaeosols (interglacials) and lower values in loess (glacials). In China, magnetic susceptibility was found to reflect the intensity of pedogenesis, which in turn leads to enhancement of magnetic minerals in soils. However, in other parts of the world under different climatic conditions, even depletion of the magnetic fraction could be observed. Furthermore, the wind strength during dust transport and loess deposition also seems to control the magnetic mineralogy. With stronger winds, minerals with higher density such as iron oxides are enriched during aeolian transport. For a detailed discussion of these phenomena, we refer to Evans \& Heller $(2001,2003)$.

The enhancement of magnetic minerals in loess during pedogenesis is by far the most important process that defines the magnetic properties of most loess deposits. The models that deal with the enhancement processes are essential for understanding the direct mineralogical reasons for magnetic susceptibility enhancement. The formation of ferrimagnetic minerals in the course of pedogenesis is the most important mechanism. Its rate and the equilibrium between the formation of magnetite/maghemite and other Fe-minerals are controlled by conditions in the soil environment such as temperature, moisture, $\mathrm{pH}$ and content of organic matter (Evans \& Heller 2001). The most widely 


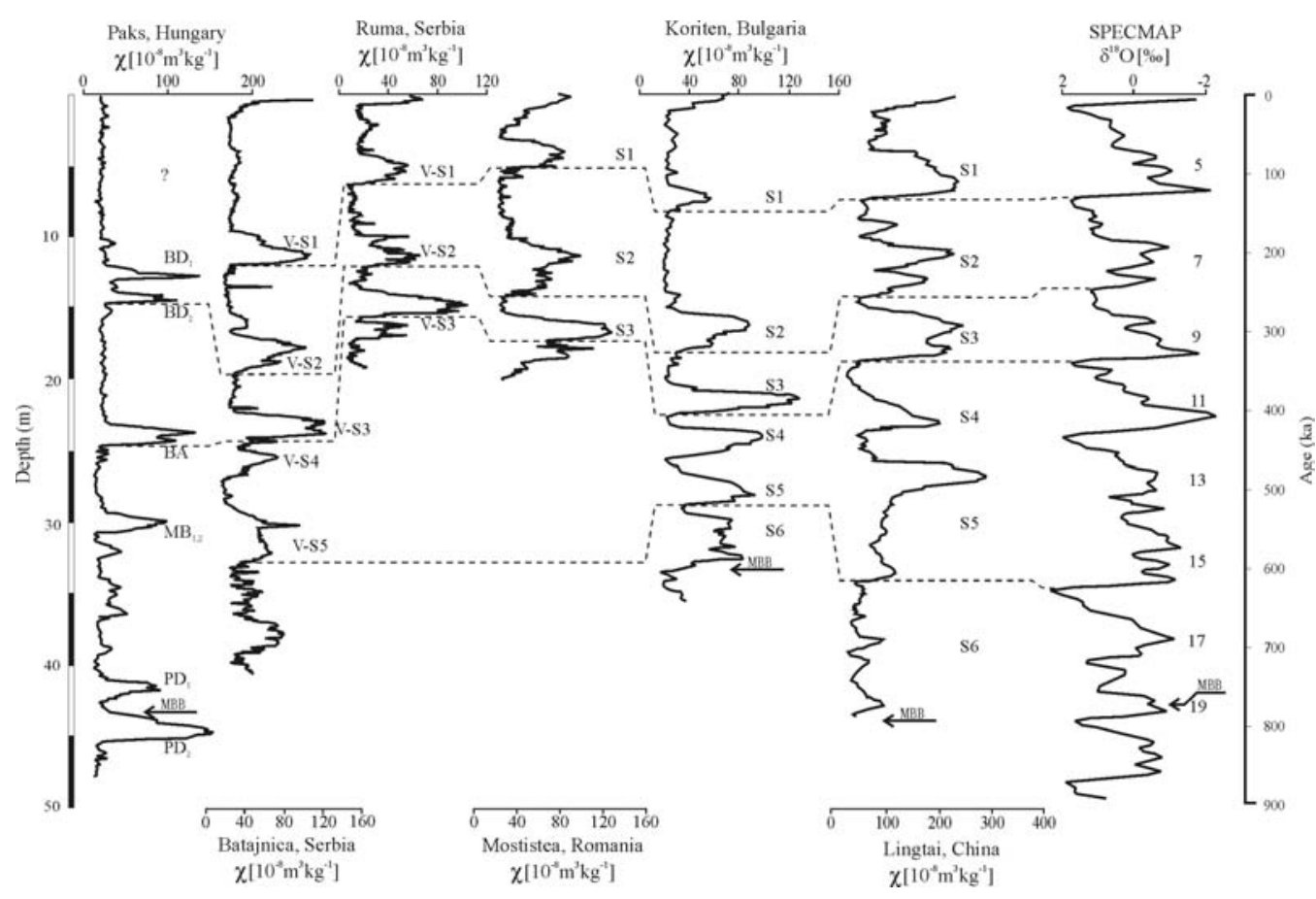

Fig. 11: Correlation of magnetic susceptibility records from Paks (SARTORI et al. 1999), Batajnica, Ruma (Marković et al. 2006), Mostistea (Panaiotu et al. 2001) and Koriten (Jordanova \& Petersen 1999), with the astronomically calibrated MS curve of the Chinese loess site Lingtai (Sun et al. 2006) and with the SPECMAP oxygen isotope record (IMBRIE et al. 1984). Note that all SE-European sections are plotted on the depth scale of the loess profiles at Paks. From Markovic et al. (submitted).

Abb. 11: Korrelation von magnetischen Suszeptibilitäts Kurven aus Paks (SARTORI et al. 1999), Batajnica, Ruma (Marković et al. 2006), Mostistea (Panaiotu et al. 2001) und Koriten (Jordanova \& Petersen 1999) mit der astronomisch kalibrierten MS Kurve des chinesischen Lössprofils Lingtai (SuN et al. 2006) und mit der SPECMAP Sauerstoffisotopenkurve (IMBRIE et al. 1984). Zu beachten ist, dass alle SE-europäischen Profile mit dem Tiefenmaßstab des Lössprofils Paks gezeichnet wurden. Aus MarKovic et al. (submitted).

accepted model (CHEN et al. 2005; EvANS \& Heller 2001; MAHer 1998; Thompson \& OldFIELD 1986) assumes alternating reducing and oxidizing conditions in the beginning, which leads to a release of $\mathrm{Fe}^{2+}$ from the weathering of iron minerals. For the whole process, the relevance of iron-reducing bacteria is stressed by several authors (CHEN et al. 2005; EvANS \& Heller 2003; MAHer 1998). Finally, magnetite of extremely fine grain size is formed by dehydration and is still susceptible for dissolution. Only further oxidation to maghemite results in a more stable ferrimagnetic mineral giving the palaeosols in loess their magnetic characteristics (BugGLE et al. in press; MAHER 1998).

Many previous investigations of loess-palaeosol sequences around the world have used MS as a basis for differentiating widespread loess and palaeosol units, correlating them regionally and relating them to the deep-sea isotope stratigraphy (e.g., Heller \& Evans 1996; Evans \& Heller 2001). Recently thick loess deposits from the Carpathian region were also studied using magnetic proxies. The application of the Chinese loess stratigraphical scheme (HELLER \& LIU 1984) necessitates a serious revision of the earlier chronostratigraphic interpreta- 
tions of the loess-palaeosol sequences in the Danube basins. In Figure 11, MS records from loess sections from the Middle and Lower Danube Basin (Hungary and Serbia to Romania and Bulgaria) are presented. The more than $40 \mathrm{~m}$ thick loess-palaeosol sequences on the Danube banks near Batajnica, Serbia, are characterised by sharp environmental differences between high dust accumulation rates during the glacials and reduced dust fluxes in the periods of palaeosol formation (MARKOVIC et al., submitted). The correlation of the MS record at Batajnica to other records from the region as well to the global ice volume record (IMBrie et al. 1984), leads to a revised chronostratigraphic frame that yields deposition of loess during the last five interglacial-glacial cycles. This example demonstrates on the one hand the potential of MS stratigraphy as an indirect dating tool for the Middle and Upper Pleistocene across Eurasia and on the other hand its potential for analysing the long-term environmental dynamics within the context of regional, continental and global climate changes.

\section{Summary and outlook}

In our overview, we pointed out the potential of the largely underdeveloped application of magnetic dating techniques in the Quaternary. Though magnetic dating is already well established for marine sediments and volcanic rocks, in terrestrial sedimentary archives and for archaeological materials, its implementation is far from exhausted. Since the early 1980s, magnetostratigraphic and magnetic susceptibility dating has been extensively applied to Asian loess sequences. However, their applications to other loess provinces around the world and to other terrestrial sedimentary archives still lacks a breakthrough. While the refinement of the geomagnetic polarity time scale for the past $200 \mathrm{Ma}$ has slowed down in recent times, a new potential seems to arise from the geomagnetic instability time scale for the past few Ma. High precision ${ }^{40} \mathrm{Ar} /{ }^{39} \mathrm{Ar}$ isochron dating now allows the correlation of geomagnetic excursions recorded in volcanic rocks with the worldwide relative palaeointensity stack of marine sequences. This provides a new and additional possibility for magnetostratigraphic dating for the Quaternary. The use of geomagnetic excursions as time markers in the Brunhes and Matuyama chrons, in combination with relative palaeointensity records derived from the same archives, will open a new perspective for dating of Middle and Lower Pleistocene sequences which are hardly datable by other methods.

As the Quaternary is the first period in Earth's history in which the climate and the biosphere are influenced by non-system players (humans), the knowledge about past climates is essential for our understanding of future climate change. Magnetic dating techniques are among the few dating methods, which can be applied to a wide range of geological archives and that can help us to decipher what happened in the past and can help improve predictions of future climate changes.

We have hopefully demonstrated the success and achievements of palaeo- and rock magnetism in earth science in general and for Quaternary research in particular and we would be very pleased, if our contribution publicises magnetic dating techniques to a broader geoscientific audience.

\section{Acknowledgements}

The authors would like to thank, first of all, Frank Preusser, the editor of this special volume of Quaternary Science Journal (Eiszeitalter und Gegenwart). Without his persistent encouragement and never ending patience, this paper would never have been finished. Constructive reviews by Thomas Fredrichs, Robert Scholger and an anonymous reviewer significantly improved the quality of the manuscript.

\section{References}

Bassinot, F. V., Labryie, L. D., Vincent, E., Quidelleur, X., Shackleton, N. J. \& Lancelot, Y. (1994): The astronomical theory of climate and 
the age of Brunhes-Matuyama magnetic reversal. - Earth Planetary Science Letters, 126: 91-108.

Bleil, U. \& von Dobeneck, T. (1999): Geomagnetic events and relative paleointensity records - Clues to high resolution paleomagnetic chronostratigraphies of Late Quaternary marine sediments? - In: Fischer, G. \& Wefer, G. (eds.): Use of proxies in Paleoceanography: Examples from the South Atlantic: 635-665; Berlin (Springer Verlag).

The Pliocene and Quaternary fluvial archives of the Rhine system. - Quaternary Science Reviews, 25: 550-574.

Boenigk, W. \& Frechen, M. (2005): The Pliocene and Quaternary fluvial archives of the Rhine system. - Quaternary Science Reviews, 25: 550-574.

Bowles, J., Gee, J., Hildebrand, J. \& Tauxe, L. (2002): Archaeomagnetic intensity results from California and Ecuador: evaluation of regional data. - Earth and Planetary Science Letters, 203: 967-981.

Brandt, U., Nowaczyk, N. R., Ramrath, A., Brauer, A., Mingram, J., Wulf, S. \& Negendank, J. F. W. (1999): Palaeomagnetism of Holocene and Late Pleistocene sediments from Lago di Mezzano and Lago Grande di Monticchio (Italy): initial results. - Quaternary Science Reviews, 18: 961-976.

Buggle, B., Hambach, U., Glaser, B., Gerasimenko, N., Marković, S., Glaser, I., Zöller, L. (in press): Stratigraphy and spatial and temporal paleoclimatic trends in East European loess paleosol sequences. - Quaternary International (2008), doi:10.1016/j.quaint.2008.07.013.

Butler, R. F. (1992): Paleomagnetism: magnetic domains to geological terranes. $-319 \mathrm{~S}$; Boston (Blackwell). [available online - http: //www.geo.arizona.edu/Paleomag/book/]

Cande, S. C. \& Kent, D. V. (1995): Revised calibration of the geomagnetic polarity timescale for the Late Cretaceous and Cenozoic. - Journal of Geophysical Research, B100: 6093-6095.

Carcaillet, J. T., Bourle`s, D. L. \& Thouveny, N. (2004): Geomagnetic dipole moment and ${ }^{10} \mathrm{Be}$ production rate intercalibration from authigenic ${ }^{10} \mathrm{Be} /{ }^{9} \mathrm{Be}$ for the last $1.3 \mathrm{Ma}$ - Geochemistry, Geophysics, and Geosystems, 5, Q05006, doi: 10.1029/2003GC000641.

Casas, L. \& Incoronato, A. (2007): Distribution analysis of errors due to relocation of geomagnetic data using the 'Conversion via Pole' (CVP) method: implications on archaeomagnetic data.Geophysical Journal International, 169 (2): 448454, doi:10.1111/j.1365-246X.2007.03346.x.

Channell, J. E. T. (1999): Geomagnetic paleointen- sity and directional secular variation at Ocean Drilling Program (ODP) site 984 (Bjorn Drift) since 500 ka: comparisons with ODP site 983 (Gardar drift). - Journal of Geophysical Research B: Solid Earth, 104, (B10): 22937-22951.

Channell, J. E. T. (2006): Late Brunhes polarity excursions (Mono Lake, Laschamp, Iceland Basin and Pringle Falls) recorded at ODP Site 919 (Irminger Basin). - Earth and Planetary Science Letters, 244: 378-393.

Channell, J. E. T., Curtis, J. H. \& Flower, B. P. (2004b): The Matuyama-Brunhes boundary interval (500-900 ka) in North Atlantic drift sediments. - Geophysical Journal International, 158: 489-505.

Channell, J. E. T., Kent, D. V., Lowrie, W. \& Meert, J. G. (2004a): Timescales of the paleomagnetic field. - 320 S.; Washington DC (American Geophysical Union).

Chen, T., Xu, H., Xie, Q., Chen, J., Ji, J. \& Lu, H. (2005): Characteristics and genesis of maghemite in Chinese loess and paleosols; mechanism for magnetic susceptibility enhancement in paleosols. - Earth Planetary Science Letters, 240, (3-4): 790-802.

Clement, B. M. \& Kent, D. V. (1987): Short polarity intervals within the Matuyama: transition field records from hydraulic piston cored sediments from the North atlantic. - Earth and Planetary Science Letters, 91: 253-264.

Collinson, D. W., Creer, K. M. \& Runcorn, S. K. (1967): Methods in Palaeomagnetism. - 609 S.; Amsterdam, New York (Elsevier).

Collinson, D. W. (1983): Methods in Rock Magnetism and Paleomagnetism. - 503 S.; London, New York (Chapman and Hall).

Cooke, H.B.S., Hall, J.M. \& Ronai, A. (1979): Paleomagnetic, sedimentary and climatic records from boreholes at Devavanya and Vesztö, Hungary. - Acta Geologica Hungarica, 22: 89-109.

Courtillot, V., Besse, J., Vandamme, D., Montigny, R., JAEGER, J.-J. \& CAPPETTA, H. (1986): Deccan flood basalts at the Cretaceous/Tertiary boundary? - Earth and Planetary Science Letters, 80: 361-374.

Courtillot, V., Gallet, Y., Le Mouël, J.-L., FluTEAU, F. \& Genevey, A. (2007): Are there connections between the Earth's magnetic field and climate? - Earth and Planetary Science Letters, 253: 328-339.

Cox, A., Dalrymple, G. B. \& Doell, R. (1967): Reversals of the Earth's Magnetic Field. - Scientific American, 216: 44-54. 
De Marco, E., Spassov, S., Kondopoulou, D., ZananIRI, I. \& Gerofoka, E. (2008a): Archaeomagnetic study and dating of a Hellenistic site in Katerini (N. Greece).- Physics and Chemistry of the Earth, 33: 481-495, doi:10.1016/j.pce.2008.02.017.

De Marco, E., Spatharas, V., Gómez-Paccard, M., Chauvin, A. \& Kondopoulou, D. (2008b): New archaeointensity results from archaeological sites and variation of the geomagnetic field intensity for the last 7 millennia in Greece. - Physics and Chemistry of the Earth, 33: 578-595, doi: 10.1016/j.pce.2008.02.025.

DunLop, D. J. \& ÖZdemir, Ö. (1997): Rock Magnetism: Fundamentals and frontiers. - 573 S.; Cambridge (Cambridge University Press).

Evans, M. E. \& Heller, F. (1994): Magnetic enhancement and palaeoclimate: study of a loess/palaeosol couplet across the loess plateau of China. - Geophysical Journal International, 117: 257-264.

Evans, M. E. \& Heller, F. (2001): Magnetism of loess/palaeosol sequences: Recent developments. - Earth-Science Reviews, 54: 129-144.

Evans, M. E. \& Heller, F. (2003): Environmental Magnetism - Principles and Applications of Enviromagnetics. - 299 S.; San Diego, (Academic Press).

Frank, U., Nowaczyk, N. R. \& Neggendank, J. (2007): Palaeomagnetism of greigite bearing sediments from the Dead Sea, Israel. - Geophysical Journal International, 168: 904-920.

Fuller, M. (2006): Geomagnetic field intensity, excursions, reversals and the 41,000-yr obliquity signal. - Earth and Planetary Science Letters, 245: 605-615.

Gabunia, L., Vekua, A., Lordkipanidze, D., Swisher, C.C., Ferring, R., Justus, A., Nioradze, M., Tvalchrelidze, M., Anton, S.C., Bosinski, G., Joris, O., de Lumley, M.A., Majsuradze, G. \& Mouskhelishvili, A. (2000): Earliest Pleistocene hominid cranial remains from Dmanisi, Republic of Georgia: Taxonomy, geological setting, and age. - Science, 288: 1019-1025.

Gallet, Y., Genevey, A. \& Le Goff, M. (2002): Three millennia of directional variation of the Earth's magnetic field in western Europe as revealed by archaeological artefacts. - Physics of the Earth and Planetary Interiors, 131: 81-89.

Gómez-Paccard, M., Catanzariti, G., Ruiz-Martínez, V. C., McIntosh, G., Núnez, J. I., Osete, M. L., Chauvin, A., Lanos, P., Tarling, D. H., Bernal-Casasola, D., Thiriot, J. \& Group, A. W. (2006a): A catalogue of Spanish archaeomagnetic data. - Geophysical Journal Interna- tional, 166: 1125-1143, doi: 10.1111/j.1365246X.2006.03020.x.

Gómez-Paccard, M., Chauvin, A., Lanos, P., McIntosh, G., Osete, G., Catanzariti, M. L., Ruiz-Martínez, V. C \& NúÑEz, J. I. (2006b): First archaeomagnetic secular variation curve for the Iberian Peninsula: Comparison with other data from Western Europe and with global geomagnetic field models. - Geochemistry, Geophysics, Geosystems G ${ }^{3}$, 7: Q12001, doi: 10.1029/2006GC001476.

GubBins, D. (1999): The distinction between geomagnetic excursions and reversals. - Geophysical Journal International, 137 (1): F1- F4.

GubBins, D. (2008): Geomagnetic reversals. - Nature Earth Science, 452: 165-167.

GuYodo, Y. \& VALET, J-P. (1999): Global changes in intensity of the Earth's magnetic field during the past 800 kyr. - Nature, 399: 249-252.

Hamano, Y. (1980): An experiment on the postdepositional remanent magnetization in artificial and natural sediments. - Earth and Planetary Science Letters, 51: 221-232.

Hambach, U. \& KrumsieK, K. (2000): Magnetische Polaritätsstratigraphie. - In: Stratigraphische Kommission Deutschlands (ed.): Stratigraphie von Deutschland III - Die Kreide in der Bundesrepublik Deutschland. - Courier Forschungsinstitut Senckenberg, 226: 51-59, Frankfurt.

Hambach, U., Mangini, A., Wagner, G. A. \& Zöller, L. (1992): Physikalische Altersbestimmung der Schichtenfolge von Mauer. - In: BeInHAUER, K. W. \& Wagner, G. A. (eds): Schichten von Mauer (85 Jahre Homo erectus heidelbergensis). - 192 S., Reiß-Museum Mannheim.

Hambach, U., Zeeden, C., Hark, M., Zöller, L., Neugebauer-Maresch, C., Einwögerer, T., Händel, M. \& Simon, U. (submitted): A High resolution palaeointensity record from a Lower Austrian last glacial loess site: implications for Upper Palaeolithic chronologies. - Quartär.

Heller, F. \& Evans, M. E. (1996): Magnetoklimatologie: Mineralmagnetismus und Eiszeiten. - Naturwissenschaften, 83: 97-102.

Heller, F. \& LiU, T.-S. (1982): Magnetostratigraphical dating of loess deposits in China. - Nature, 300 (5891): 431-433.

Heller, F. \& Liu, T.-S. (1984): Magnetism of Chinese loess deposits. - Geophysical Journal of the Royal Astronomic Society, 77: 125-141.

Horng, C.-S., Lee, M.-Y., Pälike, H., Wie, K.-Y., Liang, W.-T., IIzUKa,Y. \& ToriI, M. (2002): Astronomically calibrated ages for geomagnetic 
reversals within the Matuyama chron. - Earth Planets Space, 54: 679-690.

Imbrie, J., J. D. Hays, D. G. Martinson, A. McIntyRe, A. C. Mix, J. J. Morley, N. G. Paces, W. L. Prell \& Shackleton, N.J. (1984): The orbital theory of Pleistocene climate: Support from a revised chronology of the marine $\delta 180$ record.In: Milankovitch and Climate, Part I, edited by A. Berger et al.: 269-305; Norwell, Massachusates (D. Reidel).

JaCkson, A., Jonkers, A. R. T. \& WALKer, M. R. (2000): Four centuries of geomagnetic secular variation from historical records. - Philosophical Transactions of the Royal Society of London, Series A, 358: 957-990.

JACOBS, J. A. (1994): Reversals of the Earth's magnetic field. Second edition. - 346 S.; Cambridge (Cambridge University Press).

Jordanova, D. \& Petersen, N. (1999): Paleoclimatic record from a loess-soil profile in northeastern Bulgaria II. Correlation with global climatic events during the Pleistocene. - Geophysical Journal International, 138: 533-540.

Kent, D.V. (1999): Orbital tuning and geomagnetic polarity timescales. - Philosophical Transactions of the Royal Society of London, Series A, 357: 1995-2007.

Korte, M. \& Constable, C. (2005): Continuous geomagnetic field models for the past 7 millennia: 2. CALS7K. - Geochemistry, Geophysics, Geosystems G3 , 6: 1-18, Q02H16, doi:10.1029/ 2004GC000801.

Korte, M., Genevey, A., Constable, C. G., Frank, U. \& Schnepp, E. (2005): Continuous geomagnetic field models for the past 7 millennia: 1 . A new global data compilation. - Geochemistry, Geophysics, Geosystems $\mathrm{G}^{3}, 6$ (2): 1-32, Q02H15, doi:10.1029/2004GC000800.

Kovacheva, M., Jordanova, N. \& Karloukovski, V. (1998): Geomagnetic field variations as determination from Bulgarian archaeomagnetic data. Part II: the last 8000 years. - Surveys in Geophysics, 19: 431-460.

LaJ, C. \& Channell, J.E.T. (2007): Geomagnetic Excursions. - In: Schubert, G. (ed.): Treatise on Geophysics, 5: 373-416, Amsterdam (Elsevier) .

LaJ, C., Kissel, C. \& Beer, J. (2004): High resolution global paleointensity stack since $75 \mathrm{kyr}$ (GLOPIS-75) calibrated to absolute values. - In: CHANnell, J. E. T., Kent, D. V., Lowrie, W. \& Meert, J. G. (eds): Timescales of the Paleomagnetic Field. - Geophysical Monograph Series, 145: 255-265; Washington, DC (American Geophysical Union).
Laj, C., Kissel, C., Mazaud, A., Channell, J. E. T. \& BeER, J. (2000): North Atlantic palaeointensity stack since $75 \mathrm{ka}$ (NAPIS-75) and the duration of the Laschamp event. - Philosophical Transactions: Mathematical, Physical and Engineering Sciences, 358: 1009-1025.

Langereis, C. G., Dekkers, M. J., De Lange, G. J., Paterne, M. \& van Santvoort, P. J. M. (1997): Magnetostratigraphy and astronomical calibration of the last 1.1 Myr from an eastern Mediterranean piston core and dating of short events in the Brunhes. - Geophysical Journal International, 129: 75-94.

Lanos, P. (2004): Bayesian inference of calibration curves: application to archaeomagnetism. In: Buck, C. E. \& Millard, A. R. (eds.): Tools for Constructing Chronologies: Crossing Disciplinary Boundaries. - Series: Lecture Notes in Statistics, 177: 43-82; London (Springer-Verlag).

Lanza, R. \& Meloni, A. (2006): The Earth's Magnetism: An introduction for geologists. - $278 \mathrm{~S}$; Berlin, Heidelberg, New York (Springer).

Le Borgne, E. (1955): Susceptibilité magnetique anormale du sol superficial. - Annales Geophysicae, 11: 399-419.

Le Goff, M., Gallet, Y., Genevey, A. \& Warmé, N. (2002): On archaeomagnetic secular variation curves and archaeomagnetic dating. - Physics of the Earth and Planetary Interiors, 134: 203-211.

Leonhardt, R., Matzka, J., Hufenbecher, F., SofFEL, H. C. \& HeIDER, F. (2002): A reversal of the Earth's magnetic field recorded in mid-Miocene lava flows of Gran Canaria: Paleodirections. - Journal of Geophysical Research, 107 (B1): EPM 7-1 EPM 7-12.

Leonhardt, R. \& Soffel, H. C. (2002): A reversal of the Earth's magnetic field recorded in mid-Miocene lava flows of Gran Canaria: Paleointensities. - Journal of Geophysical Research, 107 (B11): 1053-1064, doi: 10.1007/s00531-006-0089-3.

LisIECKI, L. E., \& RAYMO, M. E. (2005): A PliocenePleistocene stack of 57 globally distributed benthic d18O records. - Paleoceanography, 20: PA1003, doi:10.1029/2004PA001071.

Lund, S. P. (1996): A comparison of Holocene paleomagnetic secular variation records from North America. - Journal of Geophysical Research, 101 (B4): 8007-8024.

Lund, S. P., Stoner, J. S., Channell, J. E. T. \& Acton, G. (2006): A summary of Brunhes paleomagnetic field variability recorded in ODP Cores. - Physics of the Earth and Planetary Interiors, 156: 194-204. 
Maher, B. A. (1998): Magnetic properties of modern soils and Quaternary loessic paleosols: Paleoclimatic implications. - Palaeogeography, Palaeoclimatology, Palaeoecology, 137: 25-54.

Maher, B. A. \& Hallam, D. F. (2005): Palaeomagnetic correlation and dating of Plio/Pleistocene sediments at the southern margins of the North Sea Basin. - Journal of Quaternary Science, 20: 67-77.

Maher, B. A. \& Thompson, R. (1999): Quaternary climates, environments and magnetism. -399 S.; Cambridge (University Press).

Mankinen, E. A. \& Dalrymple, G. B. (1979): Revised geomagnetic polarity time scale for the Interval 0-5 m.y. B.P. - Journal of Geophysical Research, 84 (B2): 615-626.

Marković, S. B., Hambach, U., Catto, N., Jovanović, M., Buggle, B., Machalett, B., Zöller, L., Glaser, B. \& Frechen, M. (submitted): The Middle and Late Pleistocene loess sequences at Batajnica, Vojvodina, Serbia.

Marković, S. B., Oches, E., Sümegi, P., Jovanović, M. \& GaudenYI, T. (2006): An introduction to the Upper and Middle Pleistocene loess-paleosol sequences of Ruma section (Vojvodina, Yugoslavia). - Quaternary International, 149: 80-86.

Márton, P. \& Ferencz, E. (2006): Hierarchical versus stratification statistical analysis of archaeomagnetic directions: the secular variation curve for Hungary. - Geophysical Journal International, 164: 484-489, doi: 10.1111/j.1365246X.2006.02873.x.

McElhinny, M. W. (1973): Palaeomagnetism and Plate Tectonics. - 358 S.; London (Cambridge University Press).

McElhinny, M. W. \& McFadden, P. L. (2000): Paleomagnetism: Continents and Oceans. - $386 \mathrm{~S}$; San Diego, San Francisco, New York, Boston, London, Sydney, Tokyo (Academic Press).

Merrill, R. T., McElhinny, M. W. \& McFadden, P. L. (1996): The Magnetic Field of the Earth: Paleomagnetism, the Core, and the Deep Mantle. - International Geophysical Series, 63. - 531 S.; San Diego (Academic Press).

Nador, A., Lantos, M., Toth-MakK, A. \& ThamoBozso, E. (2003): Milankovitch-scale multiproxy records from fluvial sediments of the last 2.6 Ma, Pannonian Basin, Hungary. - Quaternary Science Reviews, 22: 2157-2175.

Nowaczyk, N. R., Frederichs, T. W., Eisenhauer, A. \& GARD, G. (1994): Magnetostratigraphic data from late Quaternary sediments from the
Yermak Plateau, Arctic Ocean: evidence for four geomagnetic polarity events in the last $170 \mathrm{ka}$ of the Brunhes Chron. - Geophysical Journal International, 117: 453-471.

Olsen, N., Lühr, H., Sabaka, T. J., Mandea, M., Rother, M., Tøffner-Clausen, L. \& Choi, S. (2006): CHAOS - A Model of Earth's Magnetic Field derived from CHAMP, Ørsted, and SAC-C magnetic satellite data. - Geophysical Journal International, 166: 67-75, doi: 10.1111/j.1365246X.2006.02959.x.

Opdyke, N. D. \& Channell, J. E. T. (1996): Magnetic Stratigraphy. - 346 S; San Diego (Academic Press).

Panaiotu C. G., Panaiotu, C. E., Grama, A. \& Necula C (2001): Paleoclimatic record from a loess-paleosol profile in southeastern Romania. - Physics and Chemistry of the Earth (A) 26: 893-898.

Panaiotu, C. G., Pecskay, Z., Hambach, U., Seghedi, I., Panaiotu, C. E., Tetsumaru, I., Orleanu, M. \& SzaKaCs, A. (2004): Short-lived quaternary volcanism in the Persani Mountains (Romania) revealed by combined $\mathrm{K}-\mathrm{Ar}$ and paleomagnetic data. - Geologica Carpathica, 55: 333-339.

Pares, J. M. \& Perez-Gonzalez, A. (1995): Paleomagnetic age for hominid fossils at Atapuerca archaeological site, Spain. - Science, 269: 830832.

Pilipenko, O. V., Abrahamsen, N. \& Trubikhin, V. M. (2006): Petro- and Paleomagnetic Investigations of Tuzla Section Sediments (Krasnodarsk Territory). - Izvestiya, Physics of the Solid Earth, 42: 344-356.

Preusser, F. (2008): Characterisation and evolution of the River Rhine system. - Netherlands Journal of Geosciences, 87: 7-19.

Reinders, J. \& Hambach, U. (1995): A geomagnetic event recorded in loess deposits of the Tönchesberg (Germany): identification of the Blake magnetic polarity episode. - Geophysical Journal International, 122: 407-418.

Reinders, J., Hambach, U., Sirocko, F., Rolf, C. \& NowACZYK, N. R. (submitted): A 50m Record of Palaeomagnetic Secular Variation retrieved from Laminated Sediments from an Eifel Maar Lake (Germany) - Evidence for a Time Interval with Low Palaeosecular Variation During MIS5.

Roberts, A. P. \& Winklhofer, M. (2004): Why are geomagnetic excursions not always recorded in sediments? Constraints from post-depositional remanent magnetization lock-in modelling. - Earth and Planetary Science Letters, 227: 345-359. 
Rolf, C., Hambach, U. \& Weidenfeller, M. (2008): Rock and palaeomagnetic evidence for the PlioPleistocene palaeoclimatic change recorded in Upper Rhine Graben sediments (Core Ludwigshafen-Parkinsel). - Netherlands Journal of Geosciences, 87: 41-50.

RoLPH, T. C. (1993): The Matuyama-Jaramillo R-N transition recorded in a loess section near Lanzhou, P. R. China. - Journal of Geomagnetism and Geoelectricity, 45: 301-318.

Rösler, W., Metzler, W. \& Appel, E. (1997): Neogene magnetic polarity stratigraphy of some fluviatile Siwalik sections, Nepal. - Geophysical Journal International, 130: 89-111.

Sartori, M., Heller, F., Forster, T., Borkovec, M., Hammann, J. \& Vincent, E. (1999): Magnetic properties of loess grain size fractions from section Paks (Hungary). - Physics of the Earth and Planetary Interiors, 116: 53-64.

SCHNEPp, E. (2007): Archäomagnetische Datierung in Deutschland und Österreich. - Archäologisches Korrespondenzblatt, 37: 313-320.

Schnepp, E. \& Hradetzky, H. (1994): Combined paleointensity and ${ }^{39} \mathrm{Ar} /{ }^{40} \mathrm{Ar}$ age spectrum data from volcanic rocks of the West Eifel field (Germany): Evidence for an early Brunhes geomagnetic excursion. - Journal of Geophysical Research, 99: 9061-9076.

Schnepp, E. \& Lanos, P. (2005): Archaeomagnetic secular variation in Germany during the past 2500 years. - Geophysical Journal International, 163: 479-490.

Schnepp, E. \& Lanos, P. (2006): A preliminary secular variation reference curve for archaeomagnetic dating in Austria. - Geophysical Journal International, 166: 91-96.

Schnepp, E., Pucher, R., Reinders, J., Hambach, U., Soffel, H. \& Hedley, I. (2004): A German catalogue of archaeomagnetic data. - Geophysical Journal International, 157: 64-78.

Singer, B., Hoffman, K., Schnepp, E. \& Guillou, H. (2008): Multiple Brunhes Chron Excursions Recorded in the West Eifel (Germany) Volcanics: Support for Long-Held Mantle Control Over the Non-Axial Dipole Field. - Physics of the Earth and Planetary Interiors, doi:10.1016/ j.pepi.2008.05.001.

Soffel, H. C. (1991): Paläomagnetismus und Archäomagnetismus. - 276 S.; Heidelberg (Springer).

Stacey, F. D. \& BanerJee, S. K. (1974): The Physical Principles of Rock Magnetism. - 195 S.; Amsterdam (Elsevier).
Sternberg, R. S. (1989): Archaeomagnetic paleointensity in the American Southwest during the past 2000 years. - Physics of the Earth and Planetary Interiors, 56: 1-17.

Stockhausen, H. (1998): Geomagnetic palaeosecular variation (0-13000 year BP) as recorded in sediments from three maar lakes from the West Eifel (Germany). - Geophysical Journal International, 135: 898-910.

StrattNer, M. \& Rolf, C. (1995): Magnetostratigraphische Untersuchungen an pleistozänen Deckschicht-Profilen im bayerischen Alpenvorland. - Geologica Bavarica, 99: 55-101.

Sun, Y., Clemens, S. C., An, Z. \& Yu, Z. (2006): Astronomical timescale and palaeoclimatic implication of stacked 3.6-Myr monsoon records from the Chinese Loess Plateau. - Quaternary Science Reviews, 25: 33-48.

Tanguy, J.-C., Le Goff, M., Principe, C., Arrighi, S., Chillemi, V., Paiotti, A., La Delfa, S. \& Patanè, G. (2003): Archeomagnetic dating of Mediterranean volcanics of the last 2100 years: validity and limits. - Earth and Planetary Science Letters, 211: 11-124.

TARLING, D. H. (1983): Palaeomagnetism: Principles and Applications in Geology, Geophysics und Archaeology. - 379 S.; London, New York (Chapman \& Hall).

TAuXe, L. (1998): Paleomagnetic principles and practice. - In: Nolet, G. (ed.): Modern Approaches in Geophysics, 17. - 299 S.; Princeton (Kluwer Academic Publisher).

Tema, E., Hedley, I. \& Lanos, P. (2006): Archaeomagnetism in Italy: A compilation of data including new results and a preliminary Italian Secular Variation curve. - Geophysical Journal International, 167: 1160-1171, doi: 10.1111/ j.1365-246X.2006.03150.x.

Thompson, R. \& OldField, F. (1986): Environmental magnetism. - 227 S.; London (Allen and Unwin).

Thouveny, N., Creer, K. M. \& Blunk, I. (1990): Extension of the Lac du Bouchet palaeomagnetic record over the last 120000 years. - Earth and Planetary Science Letters, 97: 140-161.

Thouveny, N., Carcaillet, J., Moreno, E., Leduc, G. \& Nerin,, D. (2004): Geomagnetic moment variation and paleomagnetic excursions since 400 kyr BP; a stacked record from sedimentary sequences of the Portuguese margin. - Earth and Planetary Science Letters, 219: 377-396.

TUCKER, P. (1980): A grain mobility model of postdepositional realignment. - Geophysical Journal 
of the Royal Astronomical Society, 63: 149-163.

VAN DER Voo, R. (1993): Paleomagnetism of the Atlantic, Tethys and Iapetus Oceans. - 411 S.; Cambridge (Cambridge University Press).

Valet, J.-P. \& Meynadier, L. (1993): Geomagnetic field intensity and reversals during the past four million years. - Nature, 366: 234-238.

Wagner, G. A., Fezer, F., Hambach, U., von KönigSWALD, W. \& ZöLler, L. (1997): Das Alter des Homo heidelbergensis von Mauer. - In: WAGNER, G. A. \& Beinhauer, K. W. (eds): Homo heidelbergensis von Mauer: Das Auftreten des Menschen in Europa: 124-143, Heidelberg.

Worm, H.-U., Ahmed, A. M. M., Ahmed, N. U., Islam, H. O., Hambach, U. \& Lietz, J. (1998): Large sedimentation rate in the Bengal delta: magnetostratigraphic dating of Cenozoic sediments from north-eastern Bangladesh. - Geology, 26: 487-490.

ZaGWIJN, W. H. (1992): The beginning of the ice age in Europe and its major subdivisions. - Quaternary Science Reviews, 11: 583-591.
Zananiri, I., Batt, C. M., Lanos, P., Tarling, D. H. \& Linford, P. (2007): Archaeomagnetic secular variation in the UK during the past 4000 years and its application to archaeomagnetic dating. - Physics of the Earth and Planetary Interiors, 160: 97-107.

Zeeden, C., Hambach, U., Reddersen, B., Fülling, A., Hark, M., Nowaczyk, N., Fuchs, M. \& ZöLLER, L. (2008): High resolution paleonintensity records from European last glacial loess sites. - Geophysical Research Abstracts, Vol. 10: EGU2008-A-10564, 2008; SRef-ID: $1607-$ 7962/gra/EGU2008-A-10564.

Zhu, R., Liu, Q., Pan, Y. Deng, C. \& Sun, J. (2006): Identifying the origin of the magnetic directional anomalies recorded in the Datong loess profile, north-eastern Chinese loess plateau. - Geophysical Journal International, 164: 312-318.

Zolitschka, B., Brauer, A., Negendank, J. F.W., Stockhausen, H. \& Lang, A. (2000): Annually dated late Weichselian continental paleoclimate record from the Eifel, Germany. - Geology, 28: 9, 783-786. 